\title{
Notre-Dame du Raincy and the Great War
}

\author{
ETIEN SANTIAGO \\ Indiana University, Bloomington
}

A

modern visitor encountering the church of NotreDame du Raincy might not suspect that it constitutes a monument to World War I. Located in Le Raincy, a suburb northeast of Paris, the church was built in 1923 by the brothers Auguste and Gustave Perret (18741954 and 1876-1952, respectively). Nothing on its exterior advertises its role as a war memorial (Figure 1). A stepped 43-meter bell tower, composed of bundled concrete columns and concrete block infill, sits back from the street at the center of a narrow urban plot. Directly to the rear of the tower and aligned symmetrically with it stands a long, rectangular, 14-meter concrete nave with a slightly curved roof. Above the central doors at the tower's base, a tympanum devised by the sculptor Antoine Bourdelle (a friend of Auguste Perret) displays an image typical of Christian iconography: women grieving the crucified Christ. Although the tympanum's subject might seem a nod to the mourning of French war casualties, an observer not privy to the church's memorial function would likely miss the allusion.

It is only after entering the building that the visitor finds two explicit references to the war. The first is a chapel of the dead, the second a stained glass window-one of ten that painter Maurice Denis created for the church-representing soldiers headed toward the Battle of the Ourcq (1914). ${ }^{1}$ These elements are located in marginal positions, tucked in corners around either side of the entrance, and neither calls attention to itself. Thus, the visitor moves into the tall, elongated, airy nave, finding it drenched in colored light pouring

Journal of the Society of Architectural Historians 78, no. 4 (December 2019), 454-471, ISSN 0037-9808, electronic ISSN 2150-5926. (C) 2019 by the Society of Architectural Historians. All rights reserved. Please direct all requests for permission to photocopy or reproduce article content through the University of California Press's Reprints and Permissions web page, https://www.ucpress .edu/journals/reprints-permissions, or via email: jpermissions@ucpress.edu. DOI: https://doi.org/10.1525/jsah.2019.78.4.454.

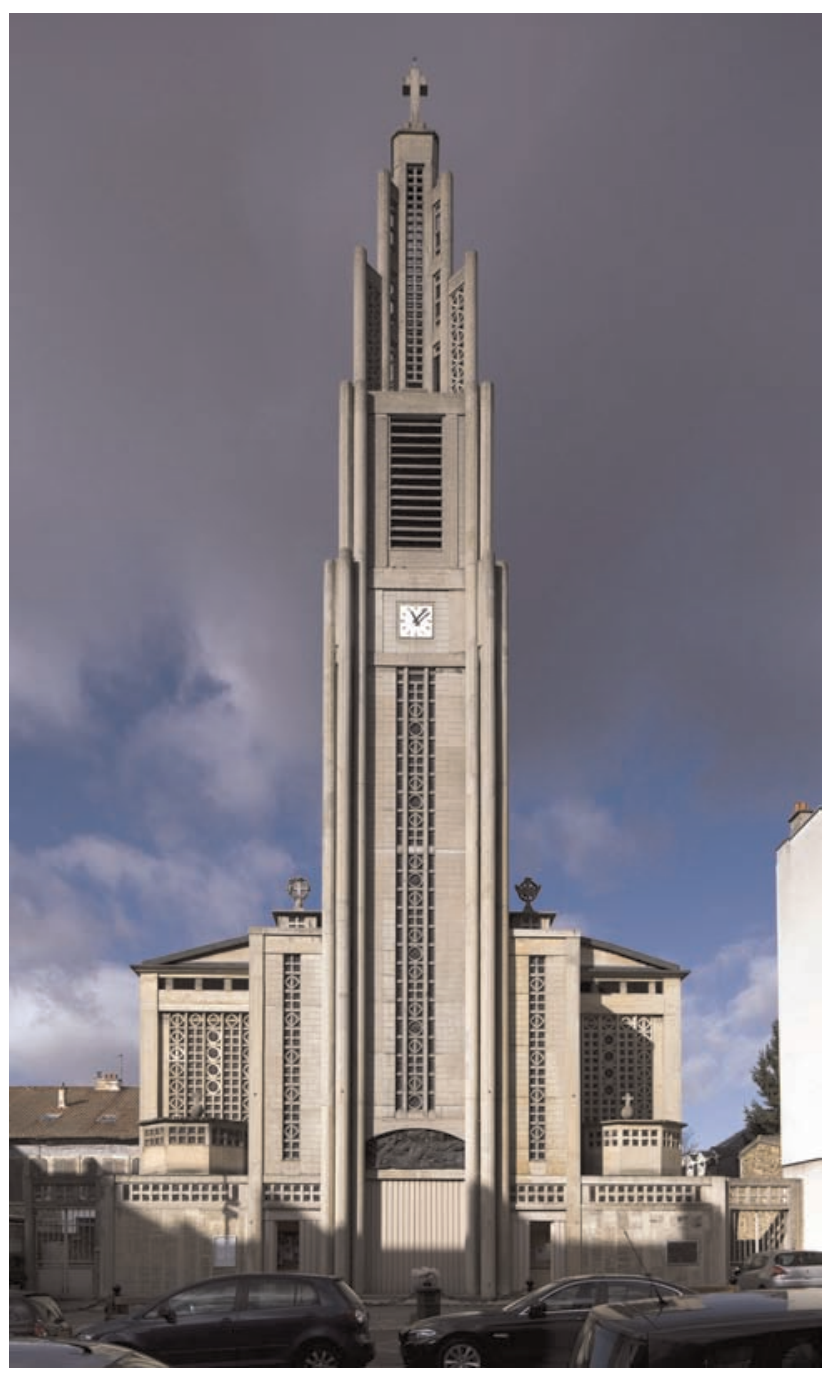

Figure 1 Perret Frères, Notre-Dame du Raincy, Le Raincy, France, 1923, front façade (photo by Barnabas Calder). 


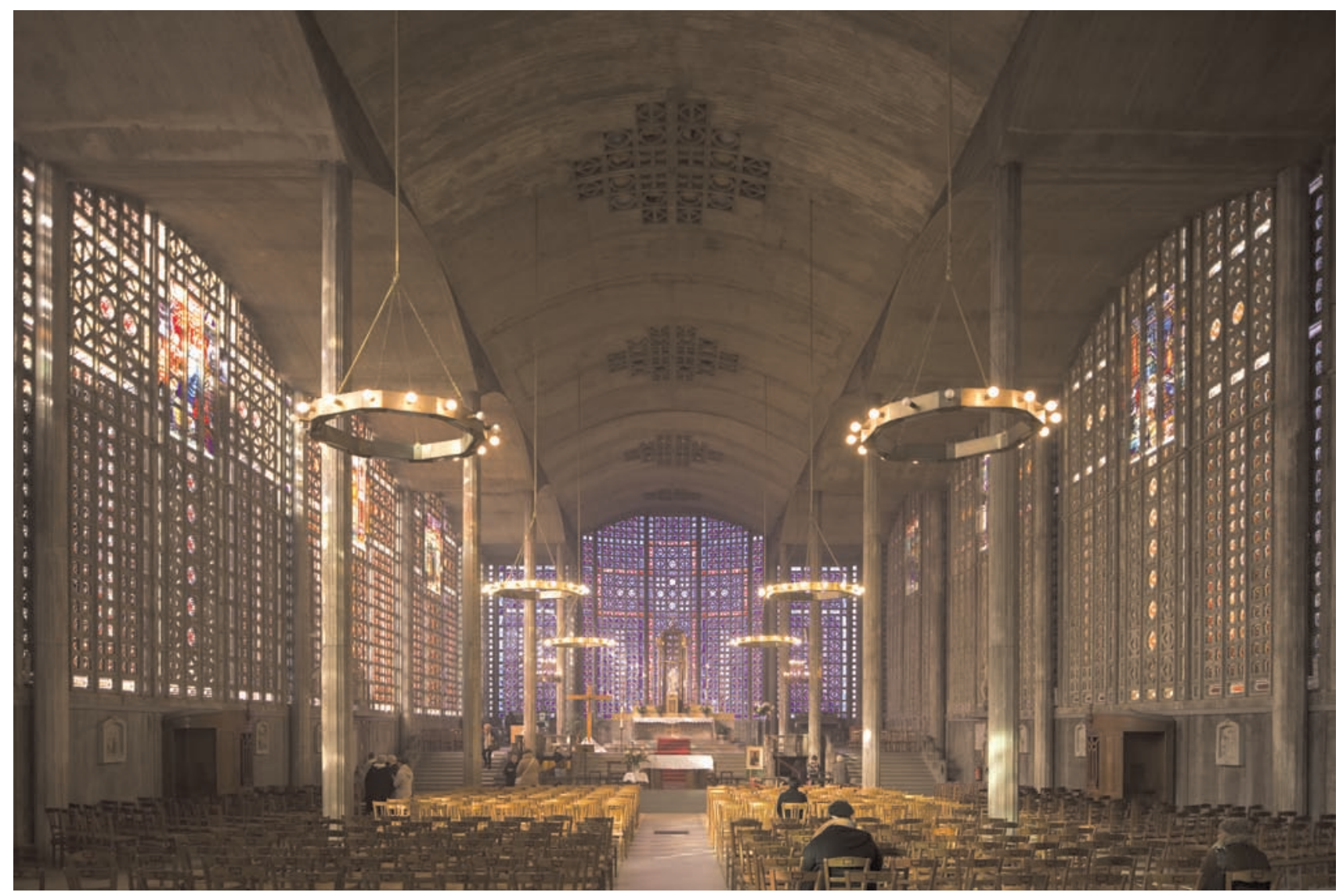

Figure 2 Perret Frères, Notre-Dame du Raincy, Le Raincy, France, 1923, view of the nave (photo by Barnabas Calder).

in through the lattice-like walls enveloping the space (Figure 2). Denis's windows are positioned toward the top and center of each bay along the building's sides. The majority of the building envelope, however, is made of perforated concrete blocks, with the perforations divided into simple shapes and filled with tinted glass. For each, the artist Marguerite Huré arranged sunflower-yellow, blood-red, indigo, cyan, and emerald-green glass pieces into a miniature composition ringed by bright white dots. ${ }^{2}$ Framed by delicate concrete mullions, the blocks produce a shimmering enclosure. Fiery rays of light stream into the church, casting dappled spots of color throughout the interior.

The light accentuates the slenderness of the fluted, tapering concrete columns supporting the flattened concrete vaults. In its delicacy and upward thrust, this structural system grants the nave a sense of amplitude and openness. The central bay, located between the innermost rows of columns, is twice as wide as the flanking bays. The vault over that middle section runs the full length of the nave, while the vaults above the side aisles are slightly lower and turned perpendicular to the central vault. Perforated blocks identical to those used on the façade are embedded into the apex of the central vault, forming geometric patterns of dark, recessed voids. These reinforce the illusion that the ceiling is a light, billowing canopy perched atop the columns. Below this, the nave floor slopes away from the front door and, thus, away from the chapel of the dead and the stained glass window honoring wartime sacrifices. The slope guides the visitor toward the altar and choir, which sit on a raised platform stretched across the width of the church. Lost amid this dazzling interior, the chapel and window seem like afterthoughts.

When their father died in 1905, Auguste Perret and his younger brothers Gustave and Claude took over the construction firm he had founded. Auguste and Gustave, having studied at the École des Beaux-Arts, oversaw design and construction, while Claude managed the finances. ${ }^{3}$ Together the brothers quickly established a reputation for high-quality work in reinforced concrete. ${ }^{4}$ Architectural historian Peter Collins has noted the influence on the Perrets of the nineteenth-century structural rationalist Eugène-Emmanuel Viollet-le-Duc, whose principles, according to Collins, Notre-Dame du Raincy embodies, blending Beaux-Arts neoclassical language with Gothic structure. ${ }^{5}$ Collins and others have identified some of the Perrets' sources. One is the cathedral of Oran, Algeria (1912), built by their father's construction firm, its windows covered with perforated concrete blocks-suggestive of the mesh-like coverings on the windows of North African claustra - that prefigure Le 
Raincy's lattice-like façade. A still earlier source was Anatole de Baudot's church of Saint-Jean de Montmartre in northern Paris, completed in 1904 and built of ciment armé (finegrained cement in which reinforcing metal is embedded). The Perret archives also contain drawings of the Hennebique company's reinforced concrete frame for Saint-Louis de Vincennes, begun southeast of Paris in 1914 according to a design by Jacques Droz and Joseph Marrast. ${ }^{6}$ In addition, historians Roberto Gargiani and Giovanni Fanelli have demonstrated that for Le Raincy's impressively slim concrete skeleton the Perrets drew on innovative techniques they developed while building industrial sheds during World War I, such as the 1917 Wallut warehouses in Casablanca, Morocco; these buildings' thin, flattened concrete vaults predate similar ones at Le Raincy by five years. ${ }^{7}$ In planning their church, the Perrets borrowed elements from all these sources while developing a new and idiosyncratic vision of what a concrete church could be.

For much of the twentieth century, studies of NotreDame du Raincy mentioned its symbolic associations with World War I in passing or not at all. ${ }^{8}$ Repeatedly described as the "Sainte Chapelle of reinforced concrete" (in reference to the thirteenth-century Parisian glass chapel), the Perrets' church is evidently visually and typologically more church than war memorial. ${ }^{9}$ Recent writings by architectural historians such as Andrew Saint, Réjean Legault, Karla Britton, Simon Texier, and Christian Freigang, however, have opened the door to more sustained investigations of its links to the war it commemorates. ${ }^{10}$ By situating the church within its larger postwar historical context, these authors have begun to unearth its once highly touted function as a memorial. Primary sources reveal that Notre-Dame du Raincy relates to the Great War in several ways. This essay examines these sources to supplement existing scholarship about the church, probing its commonalities with other French monuments of the time and with utilitarian structures created in response to the war.

\section{Symbols of the War}

The relative inconspicuousness of war-related symbols at Notre-Dame du Raincy belies the origin story of this church. It might never have been executed, in fact, without a sizable donation from an anonymous parishioner in memory of his son who died on the front lines. ${ }^{11}$ Yet the French public eventually associated Notre-Dame du Raincy not with this tragic story, but rather with an uplifting event that occurred during the war. The church was to occupy a lot in the center of Le Raincy, site of the wartime headquarters of French generals Joseph Joffre and Michel-Joseph Maunoury. ${ }^{12}$ Here, in the early days of the conflict, these officers had devised a strategy to keep Paris from falling into enemy hands. With the
German army speeding toward the French capital, Joffre and Maunoury requisitioned Parisian taxicabs to move fresh troops for a planned counterattack. About six hundred taxis were assembled on 6 and 7 September near Le Raincy. They carried between three thousand and five thousand soldiers to the front lines, about 40 kilometers east. The subsequent Battle of the Ourcq marked the start of the First Battle of the Marne, which effectively stopped the German advance and kept Paris from falling. ${ }^{13}$ Recent research has questioned the magnitude of the taxi operation's impact, but the event became legendary nonetheless-a symbol of civilian participation and Allied resolve. ${ }^{14}$

Father Nègre, the priest of Le Raincy who received the anonymous benefactor's gift, decided early on that the new church would pay tribute to the taxi story and to the historical significance of the building site. In 1922, he asked General Maunoury to serve on the patronage committee backing the project, and the general agreed. ${ }^{15}$ Throughout construction and after-the bishop of Versailles consecrated the building on 17 June 1923-French newspapers trumpeted how Notre-Dame du Raincy commemorated the taxis and the Battle of the Ourcq. While some journalists dubbed the church "Notre-Dame de la Consolation," others called it "Notre-Dame de l'Ourcq," "Notre-Dame de la Marne," or even "Saint-Taxi." "

Denis's stained glass window depicts the start of the Battle of the Ourcq, with blue-uniformed poilus (French soldiers) lining up to board civilian taxis as the Virgin Mary hovers overhead (Figure 3). On the left side of the image, the faces of Generals Maunoury and Joffre are recognizable as Joffre points imperiously toward the cars. In both content and form, this scene celebrates the union sacrée that predominantly held firm in France throughout the war, as private citizens, the Catholic Church, and the state put aside their political and ideological differences and collaborated to protect their homeland from invasion. ${ }^{17}$ Denis's window effectively conveys respect for the union sacrée while reifying the popular view of this church's connection to Le Raincy's contribution to the war effort.

Nearby within the church, the chapel of the dead is housed in a low cubic volume abutting the south side of the bell tower. An octagonal turret caps this volume. Apart from a statue of a knight and a sculpture of a dove representing the Holy Spirit, the chapel is empty (Figure 4). ${ }^{18}$ Green marble plaques hanging on the concrete walls list the names of Le Raincy's war dead. Duplicating the shape of the turret, an octagonal pattern of black lines is etched into the concrete floor. This pattern-four triangles converging to create a Maltese cross traversed by two swords-corresponds to the croix de guerre that sculptor Albert Bartholomé designed in 1915 for a French military medal commending acts of exceptional valor. ${ }^{19}$ On the chapel's floor, this cross is surrounded 


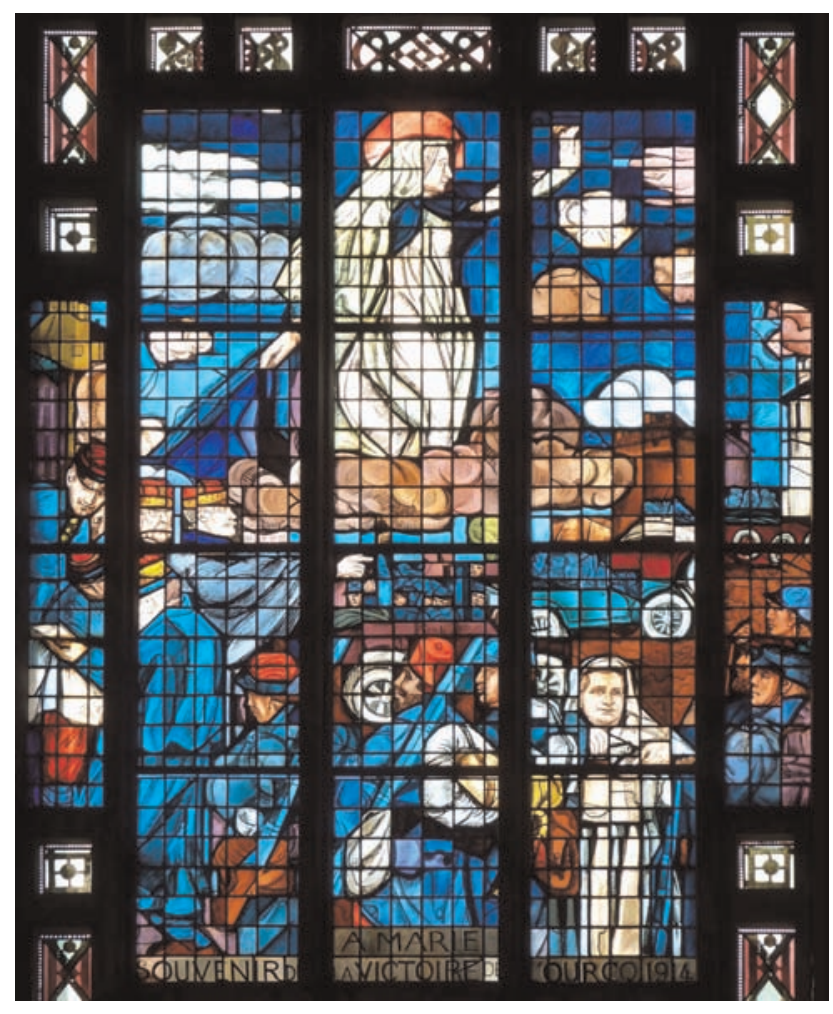

Figure 3 Maurice Denis, "À Marie, Souvenir de la victoire de l'Ourcq, 1914," in Notre-Dame du Raincy, Le Raincy, France, 1923 (author's photo).

by an inscription in Latin: "In sanguine eorum, justitia et pax osculatae" (In their blood, justice and peace meet). With its statue, its military insignia, its names of the dead, and this consoling message, the chapel adheres closely to the basic template for French municipal Great War monuments built from 1918 onward. ${ }^{20}$ Historian Antoine Prost notes that the "idea of raising monuments to the dead did not originate with World War I, but no other war spawned so many. . . . The proliferation of monuments reflected the depth of the nation's trauma." ${ }^{21}$ On 25 October 1919, the French government passed a law that encouraged the construction of such monuments, providing subsidies to towns that did so. "Most village monuments were inaugurated before 1922," writes Prost, "as each township vied with its neighbors." ${ }^{22}$ Le Raincy's chapel allowed the town's citizens to boast of their own monument, albeit one located inside a church rather than in a public square. ${ }^{23}$ Notre-Dame du Raincy thus joined a plethora of similar newly minted works utilizing approved signs of mourning to honor dead soldiers. Like these others, the church artfully promoted the idea that the soldiers' sacrifices were not in vain. ${ }^{24}$

There is a third element in Notre-Dame du Raincy that acknowledges the war, and it is easily overlooked. An article of 1924, published in La Construction moderne, notes that the topmost pier of the bell tower is comparable to a historic type

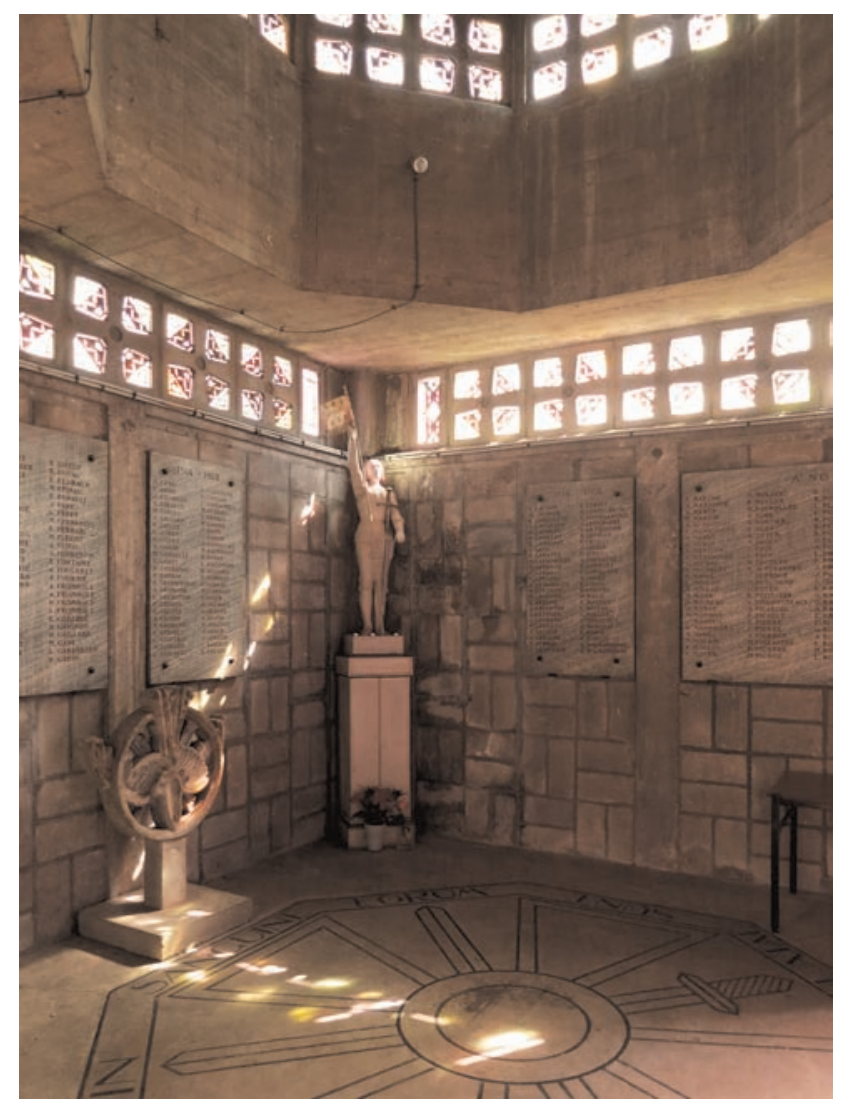

Figure 4 Perret Frères, Notre-Dame du Raincy, Le Raincy, France, 1923, view of the chapel of the dead (author's photo).

of French structure known as the lanterne des morts (lantern of the dead). ${ }^{25}$ Paul Jamot, an art critic and curator who knew the Perrets well, supported this comparison. In his 1927 monograph on the brothers, Jamot states that the "crowning cap" of the tower of Notre-Dame du Raincy "acknowledges the votive meaning of the church and recalls the souls of those who died for the salvation of France: the uppermost motif of the steeple, the last pole that surpasses all of the other ones, was inspired by those little monuments that one finds in several provinces and which are called 'lanterns of the dead.' "26 Jamot cites an entry in Viollet-le-Duc's Dictionnaire raisonné de l'architecture française $d u X I^{e}$ au XVI siècle describing lanterns of the dead as medieval structures found in French cemeteries, likely having evolved from earlier pagan traditions. ${ }^{27}$ These masonry towers culminated in small chambers pierced by openings that framed lamps whose flames were once continuously lit (Figure 5). Not only would these elevated lights signal the locations of cemeteries at night, but they would also ward off evil spirits while honoring the deceased. The tower at Le Raincy is not illuminated, but its top is punctured by openings through which the sky can be dimly perceived (see Figure 1). According to Jamot, this upper element is analogous to the elevated chambers found in lanterns of the dead. Further, because it is formally disengaged 


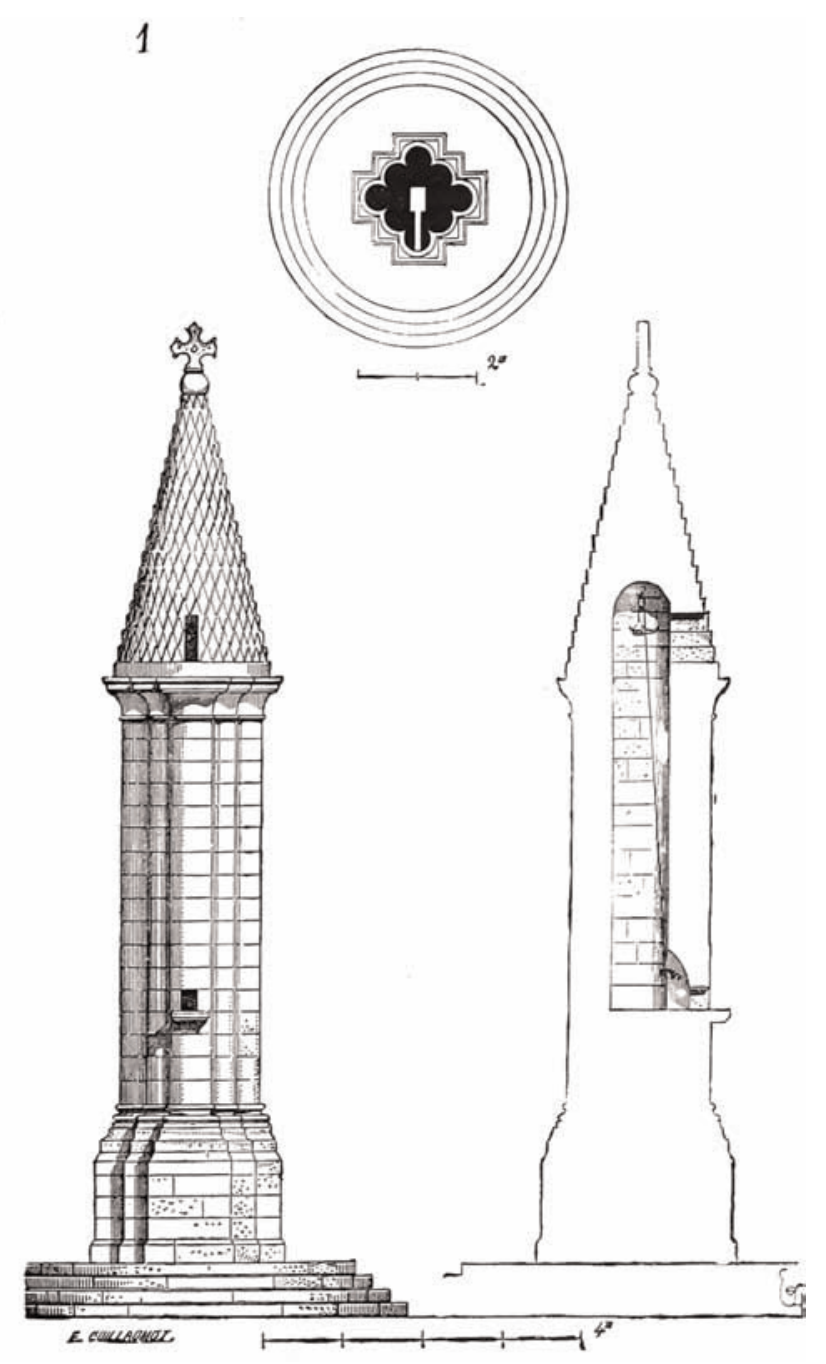

Figure 5 The medieval lantern of the dead at Cellefrouin, France (illustration in Eugène-Emmanuel Viollet-le-Duc, Dictionnaire raisonné de l'architecture française du $X l^{e}$ au XVI siècle, vol. 6 [Paris: B. Bancé, 1863], 157).

from the nave, the tower is highly evocative of these earlier structures.

By the early 1920s, a growing number of French Great War cemeteries included such lanterns. ${ }^{28}$ In July 1919, an entry titled Lanterne des Morts won an honorable mention in the competition for a monument to residents of Nice killed in the war. ${ }^{29}$ Louis-Marie Cordonnier's plan for the monument at Notre-Dame de Lorette, a 76-meter-high lantern of the dead beside the new basilica he designed, fueled the trend (Figure 6). ${ }^{30}$ This project, sited in a field of French soldiers' graves near Lens, in the Pas-de-Calais, was widely exhibited and publicized after September 1920. Newspaper articles praising it noted the suitability of reviving a long-lost French building type to commemorate the Great War. Critics viewed the solemnness of this ancient memorial type, and the symbolism of its eternal flame, as a fitting response to modern

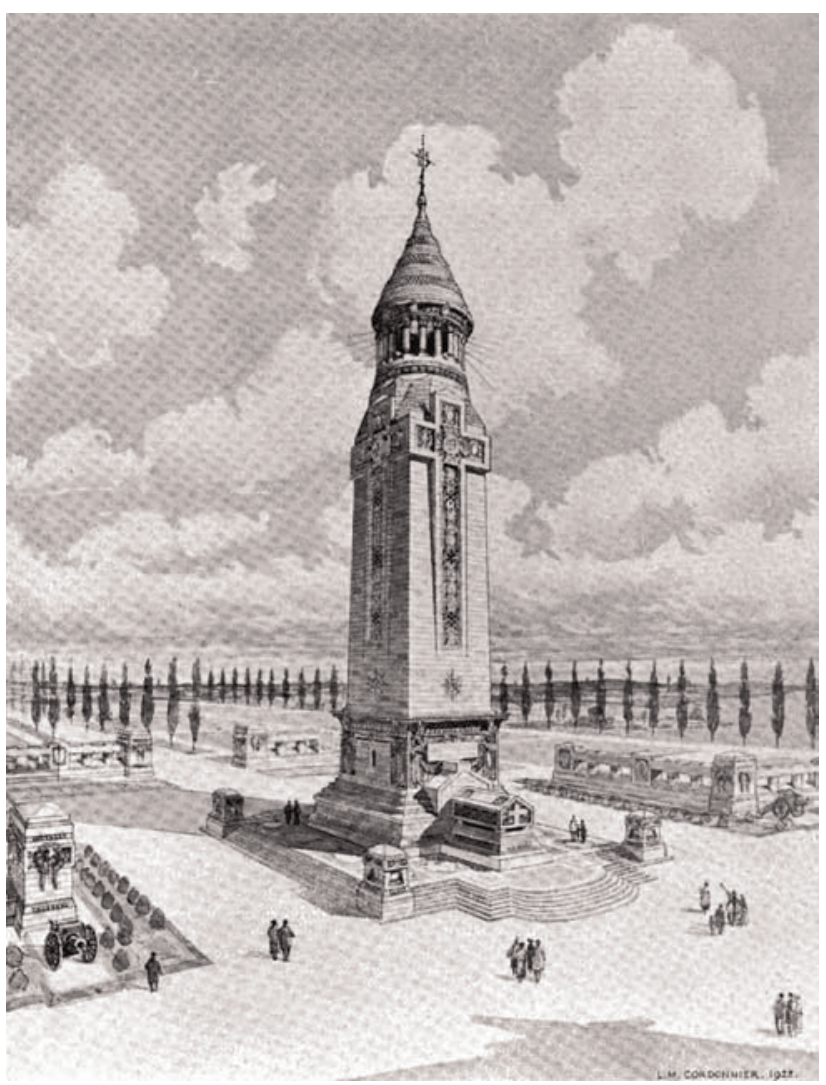

Figure 6 Louis-Marie Cordonnier, project for Notre-Dame de Lorette, France, 1922, drawing of the lanterne des morts ("Le Monument aux morts de Notre-Dame-de-Lorette," L'Illustration, 1 Apr. 1922, 294).

needs. Commenting on Cordonnier's project in a front-page article of 1921, a writer for Le Figaro proclaimed that "a 'lantern of the dead' should shine forever, in the nights of France, from the Yser to the forests of the Vosges, [as a] symbol of fidelity, gratitude, and faith." ${ }^{31}$ French veterans' associations, meanwhile, backed a grandiose proposal to erect a chain of lantern towers, spaced some distance apart at regular intervals, to illuminate the full extent of the former front lines, from the North Sea to the Swiss border. ${ }^{32}$

In the fall of 1922, while the church at Le Raincy was rising, a major competition was held for an ossuary and monument to be located in the battlefield of Douaumont, near Verdun, in memory of the 170,000 French soldiers who died there. The competition program required that the design of each entry incorporate a lantern of the dead. ${ }^{33}$ Léon Azéma's winning entry placed the tower at the center of a stocky, vaulted ossuary, its crowning room lit from inside at night (Figure 7). ${ }^{34} \mathrm{~A}$ similar competition was held two years earlier for the war memorial at Dormans, marking the First Battle of the Marne. ${ }^{35}$ Though this competition had not mandated a lantern of the dead, the winning entry-a neo-Romanesque design by Alexandre Marcel and Georges Closson—did include one (Figure 8). ${ }^{36}$ On 7 September 

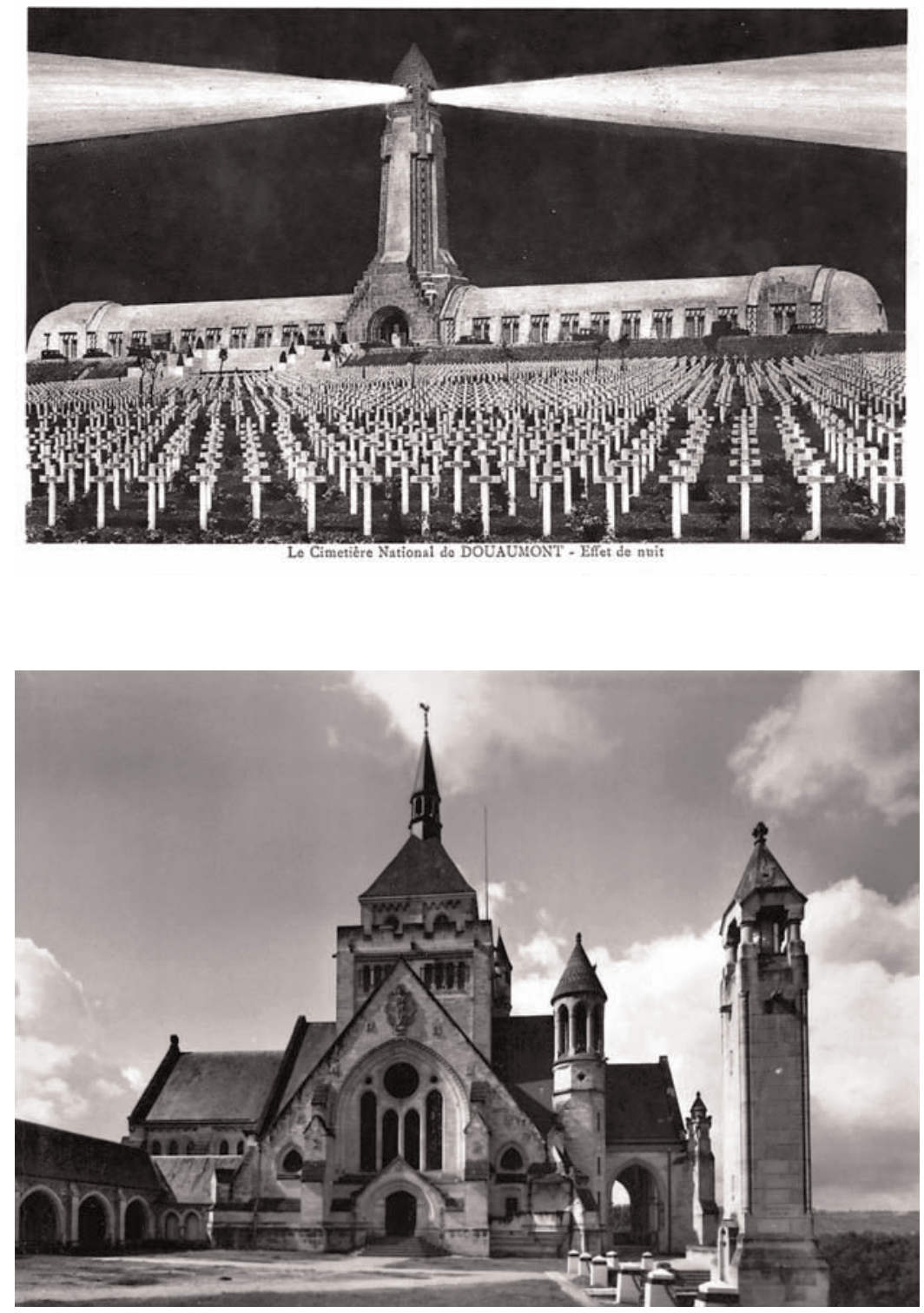

Figure 7 Léon Azéma, Ossuary of Douaumont, Douaumont, France, 1932, south side with the lanterne des morts (postcard, author's collection).

Figure 8 Alexandre Marcel and Georges Closson, Monument des Victoires de la Marne, Dormans, France, 1931 (postcard, author's collection).
1922, the art critic Abel Fabre (writing under his pen name A. Fulcran) proclaimed in La Croix that Notre-Dame du Raincy would eventually "be the counterpart of the chapel of Dormans, on the Marne." ${ }^{37}$ Offering a stylized modern take on the medieval lantern of the dead, the Perrets' bell tower nodded to similar memorials rising at Dormans and elsewhere in France during those years.

The revival of the lantern of the dead in French Great War memorial designs corresponded with visions of a unified, homogeneous nation whose roots could be traced back to the Middle Ages. Such imagery appealed to French citizens as they struggled to situate their staggering wartime losses within the context of a long and illustrious national history. ${ }^{38}$ NotreDame du Raincy contributed to this discourse by interpreting an ancient type in modern form. With its stained glass and its bell tower's stepped masses, its articulated, pier-like columns, and its tracery-like concrete block construction, the building does resemble northern French churches of the medieval era-however modern its interpretation of these elements. Notre-Dame du Raincy was part of a contemporaneous neomedieval revival that, in the wake of a brutal war, resonated with prevalent conceptions of French national identity.

The stained glass window representing the Battle of the Ourcq, the chapel of the dead, the bell tower modeled on medieval lanterns of the dead-these features catapulted NotreDame du Raincy into a wider conversation, pervasive in 1920s France, regarding the roles of art and architecture in commemorating the war. All of these elements aligned with then-widespread views about how best to address the challenge of commemoration. However, the church diverged significantly from most contemporary French war memorials in its use of materials, in particular its honest, modern display of 
unclad and untreated concrete. Yet this, too, was part of the conversation about how to commemorate the war through architecture.

\section{Commemorating World War I in Concrete and Wood}

Designers of French monuments to the Great War typically preferred traditional prestige materials such as marble or limestone; even when using less expensive structural materials-rubble stone walls, brick, reinforced concrete, metal armatures - they hid these beneath more elegant stone claddings. Marcel and Closson's memorial at Dormans, for example, is wrapped in a pale, creamy stone excavated from quarries in the Meuse and northern France. ${ }^{39}$ Azéma's monument at Douaumont has a concrete structure, but it is masked beneath a thin layer of ashen limestone. ${ }^{40}$ Cordonnier selected a pierre bleu de Givet stone from the Ardennes for Notre-Dame de Lorette. ${ }^{41}$ These buildings followed a long tradition of luxurious stone surfaces in French monumental architecture.

Notre-Dame du Raincy's small budget precluded the use of such materials. Nor was the budget large enough to allow for the laborious finishing work (to improve the concrete's appearance) that the Perrets later employed on other projects. ${ }^{42}$ Rather than masking Le Raincy's rough cast concrete surfaces with plaster or paint, the builders left them as they appeared when the formwork was removed. ${ }^{43}$ Visitors can plainly see the pockets caused by trapped air and the lumps of cement or pebbles on the thin, fluted columns. Ragged edges mark the building's right angles (Figure 9). Joints between formwork planks left inconsistent, partially frayed ridges of cement on the rectangular piers along the church's perimeter. The nave's vaulted ceiling is riddled with irregularities that echo the linear grain of the wooden formwork (Figure 10). Conspicuous dark stains are evident where larger formwork panels once abutted one another (Figure 11).

These rough surfaces exhibit an aesthetic rawness that departs significantly from the smoothness and finishes typical of most contemporary French monuments or churches. Yet two other war memorials, both conceived before 1922 by architect André Ventre, took a similar tack in showcasing their rough concrete structures. ${ }^{44}$ A 1923 article in L'Intransigeant states that Notre-Dame du Raincy was "built by the Perrets, those innovative architects who, like a few others including the architect Ventre, constructor of the monument on the Pointe de la Grave, dream of creating a style of reinforced cement." ${ }^{45}$ In fact, Ventre's Monument aux Américains at the Pointe de la Grave (along the Atlantic seaboard of southwestern France) was then but a proposal for a still-unbuilt memorial. ${ }^{46}$ French president Raymond Poincaré had originally charged Bartholomé with the project, but in 1922 Bourdelle and Ventre

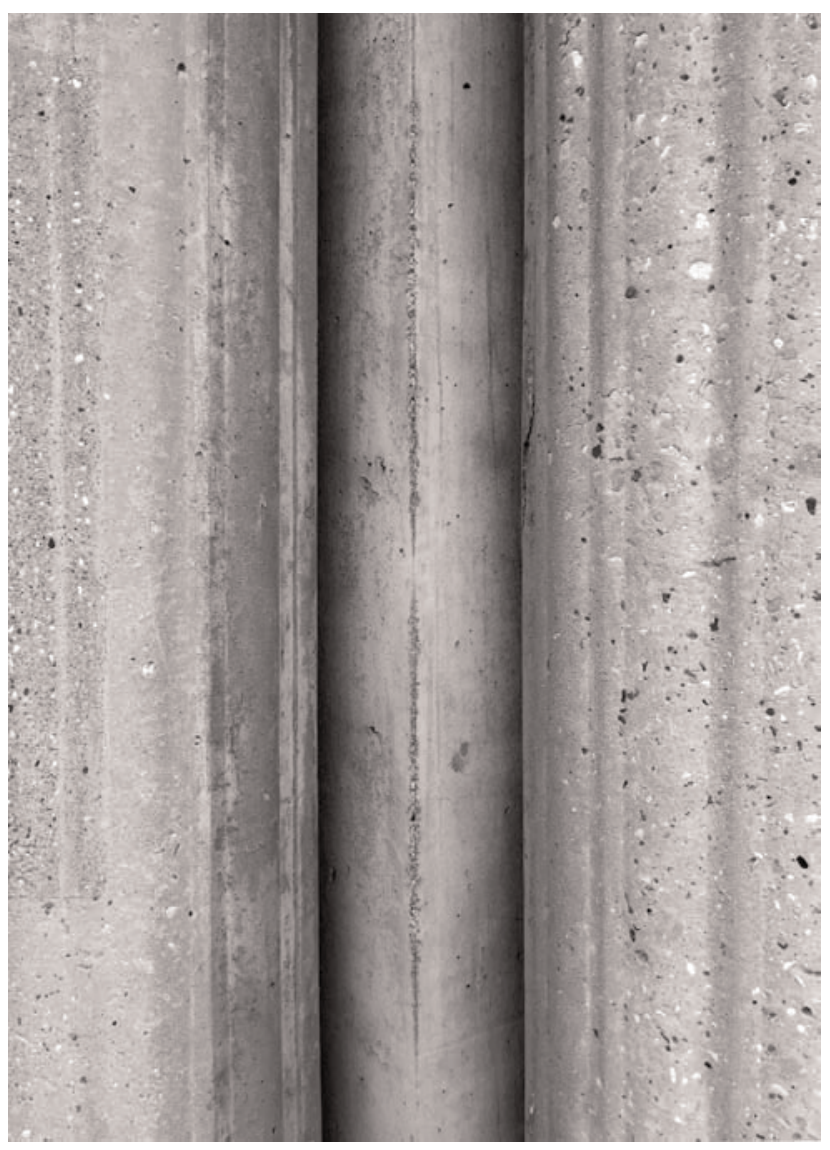

Figure 9 Perret Frères, Notre-Dame du Raincy, Le Raincy, France, 1923, detail of the concrete at the belfry columns (author's photo).

joined the design team. ${ }^{47}$ Their reworked, collaborative project was publicized the following year, along with the claim that it would be built of unclad concrete (Figure 12). ${ }^{48}$

By 1920, Ventre had completed another war memorial that candidly displayed its concrete structure: the Tranchee des Baïonnettes memorial at Douaumont, just meters away from the future site of Azéma's ossuary. ${ }^{49}$ Built to commemorate an explosion that killed an entire company of French soldiers in 1916, Ventre's low, stocky monument spans the burial trench with a massive horizontal roof supported by thick, drum-shaped columns (Figure 13). Gritty gray concrete is visible everywhere, inside and out. As with the vaults of Notre-Dame du Raincy, the huge pillars and slightly sagging surfaces of the ceiling retain the bumpy, striated imprint of the timber formwork (Figure 14). Surprisingly, perhaps, French critics lauded Ventre's decision to leave such shoddy-looking surfaces on a war memorial while shunning more lavish decorations. As one wrote:

No embellishment, no pattern, no ornament. One grasps the impropriety here of festoons and astragals. Likewise, one would not comprehend that, under the pretext of commemoration, in a devastated region where the inhabitants lived in such 


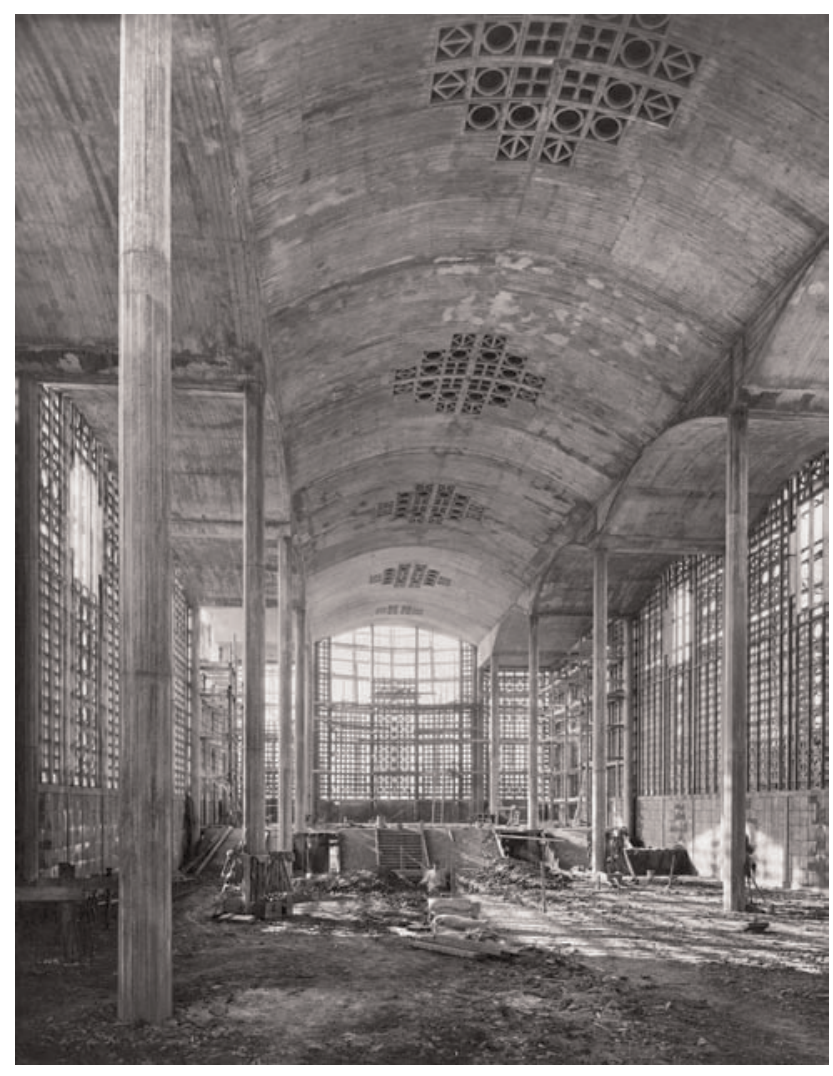

Figure 10 Perret Frères, Notre-Dame du Raincy, Le Raincy, France, 1923, view of the nave under construction (photo: Chevojon, dossier $535 \mathrm{AP}$ 653/2, document CNAM-22-01-G, Fonds Auguste Perret et Perret Frères, Centre d'Archives d'Architecture du XX $X^{e}$ Siècle, Paris; CNAM/SIAF/CAPA/ Archives d'Architecture du XXe Siècle/Auguste Perret/UFSE/SAIF/2019).

poverty, beautiful white stone or shiny marble were brought here at a high cost. No. The slab, with a thickness of more than two meters, the columns, the whole monument will be in gray cement, which is to say the material with which soldiers built their shelters, their trenches, and which is the color of war. ${ }^{50}$

According to this author, the bare concrete of the Tranchée des Baïonnettes memorial was justified not only by the poverty and suffering experienced by local civilians during the war but also by soldiers' military uses of the same material.

Indeed, during World War I, concrete construction proliferated along the western front at a rapid pace. Short on wood and metal, armies on both sides relied on this alternative material for building defensive bunkers and fortifying trenches. ${ }^{51}$ The Germans built temporary concrete shelters in 1915, and Allied armies soon followed suit. ${ }^{52}$ By the time the war ended, rugged cast concrete was a common sight on the front lines. Thus, it later seemed a fitting material for honoring soldiers who had served on those lines. Concretea drab, practical material, the "color of war"-became imbued with symbolic potential. ${ }^{53}$ Concrete military shelters on

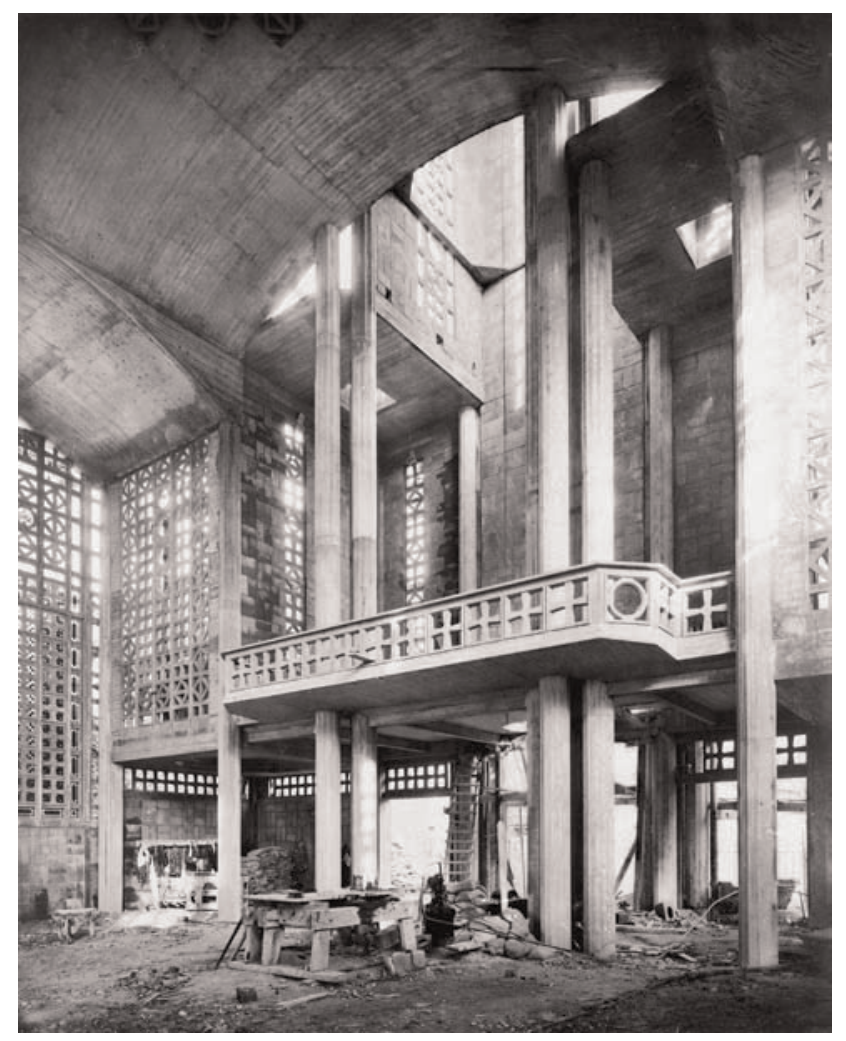

Figure 11 Perret Frères, Notre-Dame du Raincy, Le Raincy, France, 1923, view of the organ platform under construction (photo: Chevojon, dossier 535 AP 653/2, document CNAM-22-01-V, Fonds Auguste Perret et Perret Frères, Centre d'Archives d'Architecture du XX Siècle, Paris; CNAM/ SIAF/CAPA/Archives d'Architecture du XX Siècle/Auguste Perret/UFSE/ SAIF/2019).

the front lines may have even inspired the bunker-like appearance of Ventre's Tranchée des Baïonnettes memorial. Traveling in 1917 through battered parts of the Aisne region, an area that enemy forces had just relinquished after occupying it since 1914, Ventre was struck by the monumental aesthetics of German concrete bunkers. Filling several large sheets of paper, he meticulously traced their heavy, horizontal forms and bumpy, cratered surfaces (Figure 15). ${ }^{54}$ Just three years later, he deployed an analogous set of forms and surfaces in his design for a memorial to French soldiers killed by the Germans.

Unlike Ventre's low, bulky Tranchée des Baïonnettes, the church at Le Raincy is soaring and delicate. Yet both memorials feature unrefined cast-in-place concrete and rough textures. Describing the Perrets' church in the Manchester Guardian in 1926, journalist Muriel Harris stated that "the great concrete monument at Verdun over the Tranchée des baïonnettes is an attempt to realize the part played by concrete during the war." ${ }^{" 55}$ She reiterated this point a month later in her review of Notre-Dame du Raincy for the New York Times Magazine: "Perhaps the first idea that concrete of all things expressed the war, with its huge stimulation of 


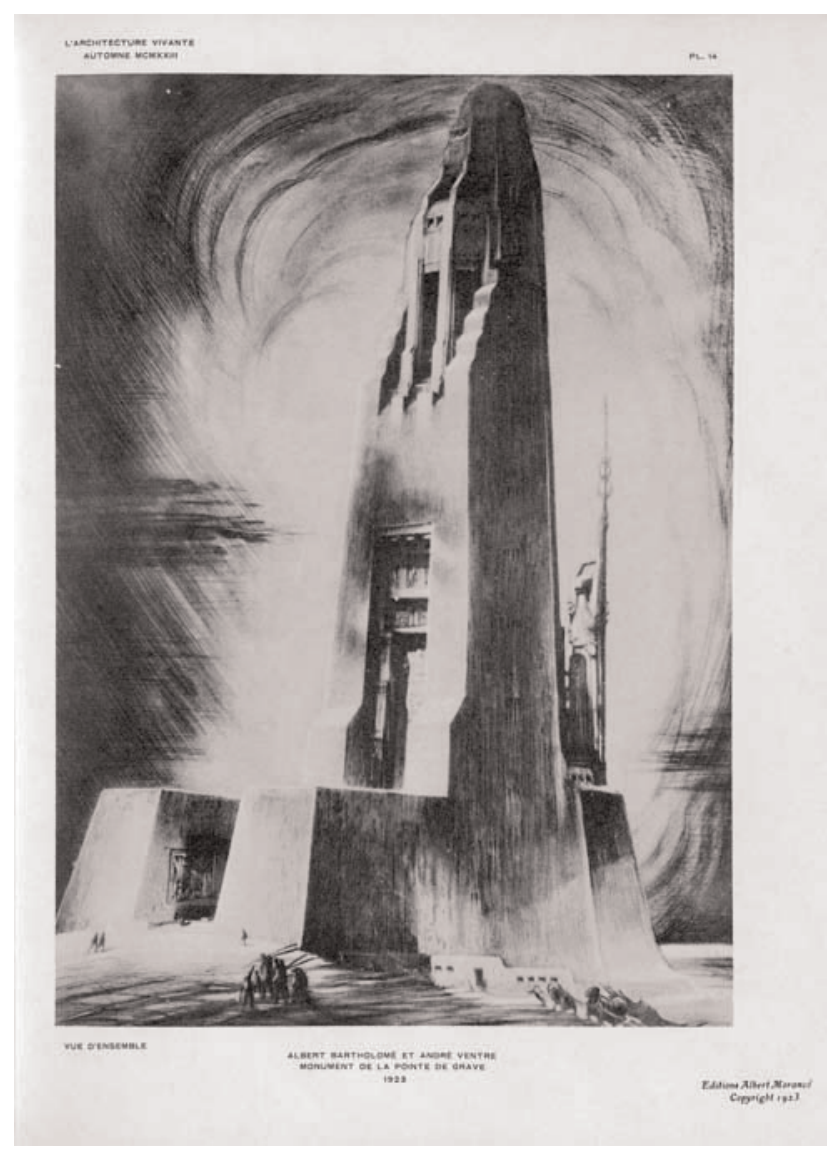

Figure 12 Albert Bartholomé and André Ventre, drawing for the Monument aux Américains at the Pointe de la Grave, Le Verdon-sur-Mer, France, 1922 (L'Architecture vivante, no. 1 [1923]).

effort, both for good and for bad, appeared in the memorial over the 'Tranchée des baïonnettes' at Verdun." ${ }^{.56}$ As Harris saw it, the unclad concrete surfaces of Notre-Dame du Raincy and the Tranchée des Baïonnettes memorial deliberately echoed the prominence of concrete on the western front. ${ }^{57}$ Moreover, she suggested, rough concrete could speak to civilians who had never seen the front lines. Although wartime disruptions brought most civilian building projects to a halt, some did proceed, and they relied heavily on concrete. ${ }^{58}$ Many were industrial in nature, directed toward the production of goods to support the army and the war effort. Designers of these structures turned to concrete for the same reasons that military engineers did: concrete was less expensive and more widely available than competing materials. From 1914 to 1918, concrete warehouses multiplied in lowdensity suburbs across France. ${ }^{59}$ Thus, citizens could indeed associate bare concrete skeletons-similar to the one at Notre-Dame du Raincy — with memories of the war.

In fact, Le Raincy was itself a working-class suburb that had experienced a boom in the construction of concrete warehouses during the war years. As Karla Britton notes, in 1923, Notre-Dame du Raincy's concrete surfaces echoed recent additions to the local built environment: during the war, the previously sleepy, traditional village was disrupted by the intrusion of concrete hangars devoted to manufacturing. ${ }^{60}$ The Perrets' church thus brought the rough industrial aesthetics of utilitarian concrete construction into the heart of the town, and into the realm of art. Britton further argues that Notre-Dame du Raincy's rough concrete conveys "a poignant restraint that reflected the lean circumstances caused by the war," again linking the edifice to the wartime experience of the population it served. ${ }^{61}$ The same conditions that rendered building materials pricey and scarce during the war also triggered a shortage of food and everyday necessities. ${ }^{62}$ Therefore, the church's concrete, in addition to borrowing a wartime aesthetic of bunkers and warehouses, could be seen as a comment on the French public's wartime privations.

Wood was another basic commodity that became rare in France during World War I. ${ }^{63}$ Unable to obtain firewood or coal for cooking and heating, French citizens of modest means resorted to burning furniture, trash, and anything else they could find during the harsh winters of 1914-15 and $1916-17 .{ }^{64}$ After the war and amid the reconstruction of the 1920s, wood remained expensive. ${ }^{65}$ Like concrete, it became evocative of wartime conditions. Maintaining traces of the timber formwork that gave it shape, the exposed concrete of Notre-Dame du Raincy speaks to the place of wood in wartime and postwar France. These traces, and the absence of the forms that made them, evoke the scarcity and effective disappearance of this basic resource during a period of strife (Figure 16). ${ }^{66}$

Notre-Dame du Raincy's materials can thus be seen to harbor several references to the war. The church's raw concrete connects it to Ventre's contemporaneous designs for concrete war memorials, to the battlefield bunkers that dotted the front lines, and to the industrial concrete sheds around Le Raincy and other French towns during the war. The material's rough treatment further evokes the dismal conditions of wartime living and the dearth of wood during those years. Yet the Perrets' design recalls the war not only through its imagery and materials. To complete the church within budget, the builders took advantage of construction methods developed in response to the war's humanitarian challenges and crippling material shortages. After the war, these methods were advanced to meet the pressing need to replace churches and houses destroyed by the fighting.

\section{Wartime Kit-of-Parts Churches and Houses}

The Great War reduced hundreds of French and Belgian towns and cities to shambles. The loss of life and habitat, along with the destruction of cultural heritage, preoccupied people around the world. ${ }^{67}$ Medieval churches were especially hard-hit. In September 1914, German bombs struck 

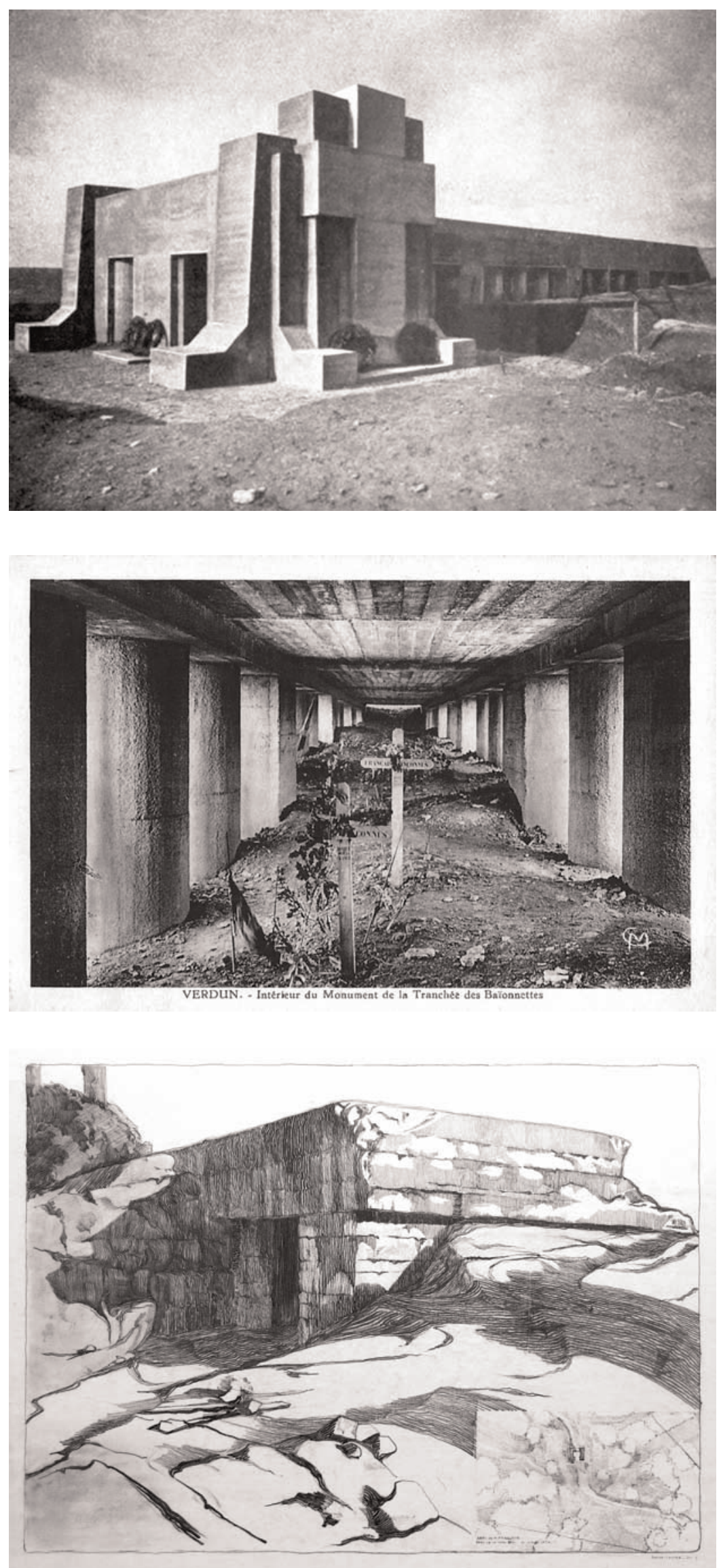

Figure 13 André Ventre, Tranchée des Baïonnettes memorial, Douaumont, France, 1920 (Verdun, Argonne 1914-1918 [Clermont Ferrand: Michelin, 1936], 100).

Figure 14 André Ventre, Tranchée des Baïonnettes memorial, Douaumont, France, 1920, interior (postcard, author's collection).

Figure 15 André Ventre, drawing of "Carlepont, abri de mitrailleuse; poste allemand," 1917 (Dist. RMN-GP, Série 0080/107/1004, Document 015279, Médiathèque de l'Architecture et du Patrimoine, Ministère de la Culture, Paris). 


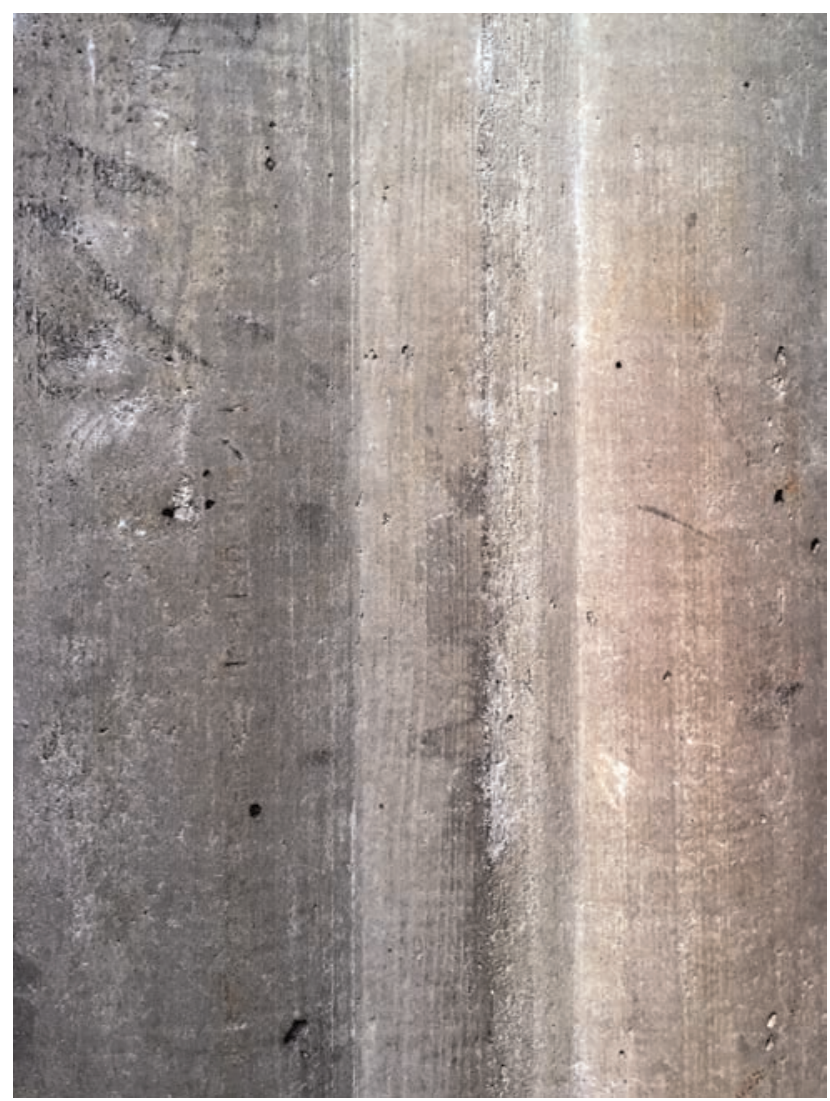

Figure 16 Perret Frères, Notre-Dame du Raincy, Le Raincy, France, 1923, detail showing traces of the wooden formwork on the concrete piers (author's photo)

the Gothic cathedral of Reims, provoking outrage among the Allies. ${ }^{68}$ Much of the building survived intact, and plans for its rebuilding quickly took hold, but many smaller village churches on the western front were damaged beyond repair. Others were converted by the German army into military strongholds, their interiors fortified with concrete. ${ }^{69}$ German forces toppled the towers of some churches, either to prevent the Allies from using their steeples as landmarks or to damage French morale. $^{70}$ Thus, like the millions of dead and wounded civilians and soldiers, towns and buildings were victims of the war.

In the fall of 1914, French pundits debated how best to deal with the loss of built heritage-in particular, the loss of places of worship. ${ }^{71}$ The fate of Reims Cathedral became an especially fraught and widespread topic. ${ }^{72} \mathrm{Au}-$ guste Perret sided neither with those who thought it should be fully restored to its former state nor with those who insisted that it be abandoned as a ruin to forever signal the war's barbarism and the damage done by the German bombs. ${ }^{73}$ He believed that the cathedral should be made usable again, but that it should be left as a partial ruin. ${ }^{74}$ Catholic and traditionalist factions, meanwhile, argued

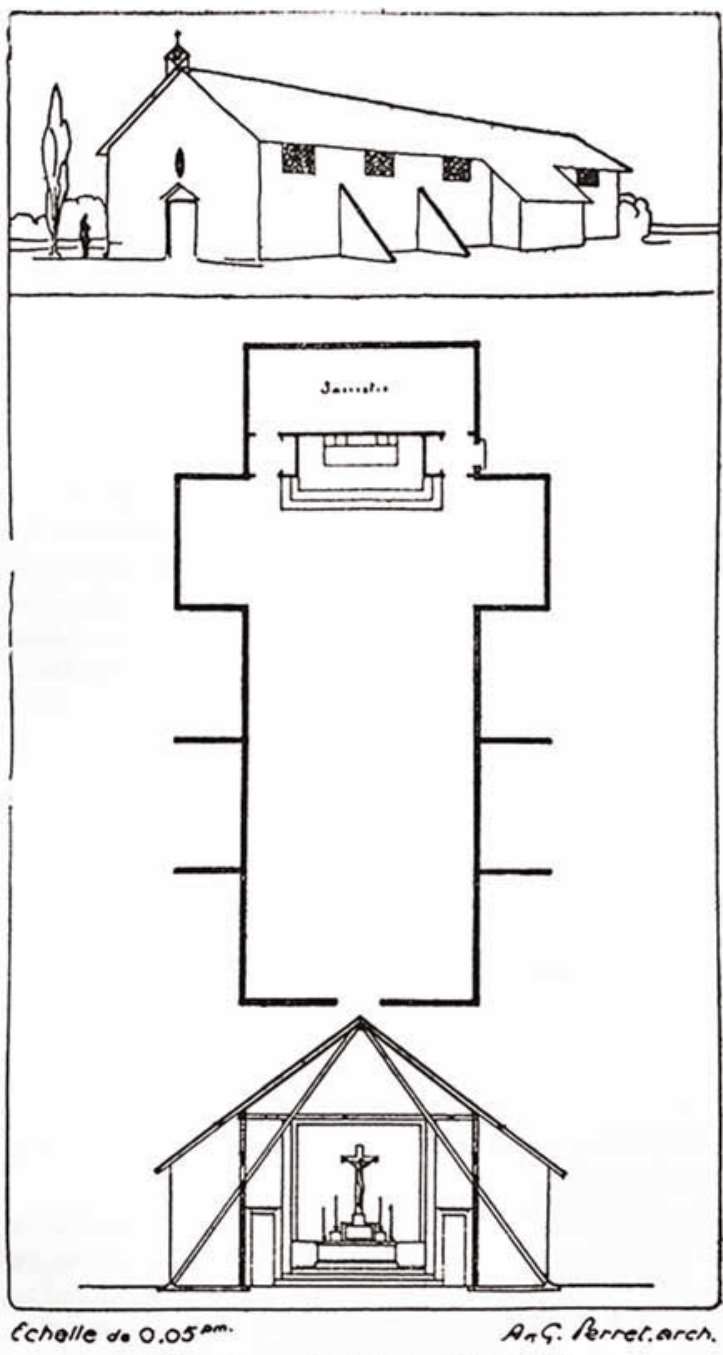

Fig. 7. - Projet de M. Perret

Figure 17 A. \& G. Perret, drawings from a competition project for an emergency church, 1916 (Abel Fabre, "La reconstruction des églises dévastées," La Vie \& les Arts liturgiques 2, no. 20 [Oct. 1915-Feb. 1916], 323).

that new churches should be built as soon as possible for the war-stricken populations in northeastern France. One organization dedicated to this effort was the Société de Saint-Jean, a Catholic group concerned with renewing religious art in France. ${ }^{75}$ Denis belonged to this group, as did Fabre. In early 1916, the society sponsored a competition for the design of temporary churches for war-torn regions. ${ }^{76}$ Auguste and Gustave Perret submitted an understated gabled project, cruciform in plan, wrapped in the double walls typical of portable wooden huts and clad with sheets of fiber cement (Figure 17). ${ }^{77}$ Only the altar inside and a small cross above the front door marked the building as a church.

A few months after this competition, the Société de SaintJean participated in a large exhibition titled La cité reconstituée, 


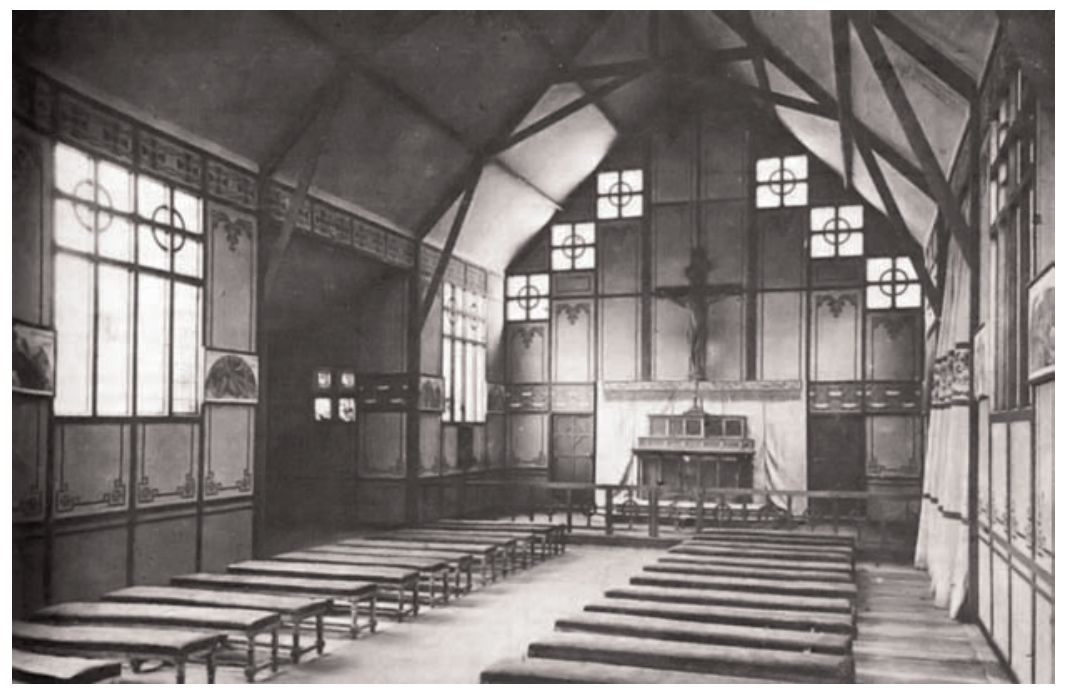

Figure 18 Placide Thomas, Chapelle de SaintJean, demountable church for the devastated regions of France, shown at the La cité reconstituée exhibition, Paris, 1916, interior ("L'exposition de la Cité reconstituée," L'Image de la Guerre 94 [Aug. 1916]).

which was held in the Tuileries gardens of Paris. The exhibition's purpose was to present remedies for the wartime destruction of France's built environment. ${ }^{78}$ Some of the displays presented long-range plans to reconstruct and enlarge existing French towns, but most of the exhibition focused on short-term solutions. Full-size mock-ups of demountable huts were built to demonstrate how inexpensive temporary shelters could be provided for families returning to villages flattened by the fighting, dwellings in which they could await the building of more permanent structures. For its contribution to La cité reconstituée, the Société de SaintJean asked the architect Placide Thomas to oversee the construction in the Tuileries of a temporary kit-of-parts church based on his entry to the 1916 competition sponsored by the society. Like other demountable huts of the time, Thomas's Chapelle de Saint-Jean was made of modular wooden panels slotted into a wooden frame (Figure 18). ${ }^{79}$ These components could be mass-produced and shipped in compact parcels to any town that needed them. ${ }^{80}$ For the chapel's interior, Maurice Denis produced twelve framed paintings depicting the martyrdom of Christ. ${ }^{81}$

Unlike Thomas's church, the skeletal structure of NotreDame du Raincy was permanently cast in place and not intended to be disassembled. Yet the Perrets relied on a logic of modular components similar to that seen in Thomas's design. Thomas utilized a repeating set of square glazed wooden frames partitioned by Greek crosses and inscribed with smaller circles. This presaged the Perrets' system of modular and geometric concrete blocks for the envelope of NotreDame du Raincy. Much as Thomas had aligned several of these wooden frames to form the banister separating the choir from the nave in his exhibition church, the Perrets, six years later, used perforated concrete blocks matching those on Notre-Dame du Raincy's façade to create a low guardrail around the church's altar (Figure 19).
In the spring of 1916, Auguste Perret declined to participate in La cité reconstituée, which he dismissed as a needless event with little potential to bring his firm commissions. ${ }^{82}$ His brother Gustave, however, contributed to the design of a demountable wooden hut displayed there: the Adrian barrack. ${ }^{83}$ After joining the French army engineering corps in the fall of 1914, Gustave had teamed up with the polytechnicien Louis Adrian to develop a functional hut suitable for military operations. ${ }^{84}$ Critic Pierre Vago, a friend of the Perrets, reported in 1932 that Gustave played a major role in the project, "which is, in large part, his work." 85 Thus, it comes as no surprise that the wooden frame of the Adrian barrackcharacterized by diagonal struts bisecting the lateral walls to anchor the roof to the ground (Figure 20)-resembles the frame of the temporary church design the Perrets submitted to the Société de Saint-Jean competition (see Figure 17).

Though neither the Perrets' cement church nor Thomas's wooden one was built across the war zone as intended, the French army produced about 100,000 Adrian barracks during World War I. ${ }^{86}$ Other Allies, notably the British and American armies, likewise developed systems for producing quick, cheap, simple buildings made of standardized parts that could be sent to remote locations and assembled by small teams of unskilled workers. ${ }^{87}$ Most such buildings were made of wood, but wartime shortages compelled the British to use metal instead for their Nissen huts. Hundreds of thousands of these structures, made of corrugated metal sheets curved around semicircular metal frames, were manufactured and distributed throughout France during the war. ${ }^{88}$ Armies on both sides built huts for use as cantonments for soldiers, hospital wards, storage sheds, and emergency housing for refugees and prisoners. After the war ended in November 1918, some of these huts were used as municipal buildings or as temporary residences for French and Belgian citizens returning to regions ravaged by war. ${ }^{89}$ Postcards of the time show Adrian 


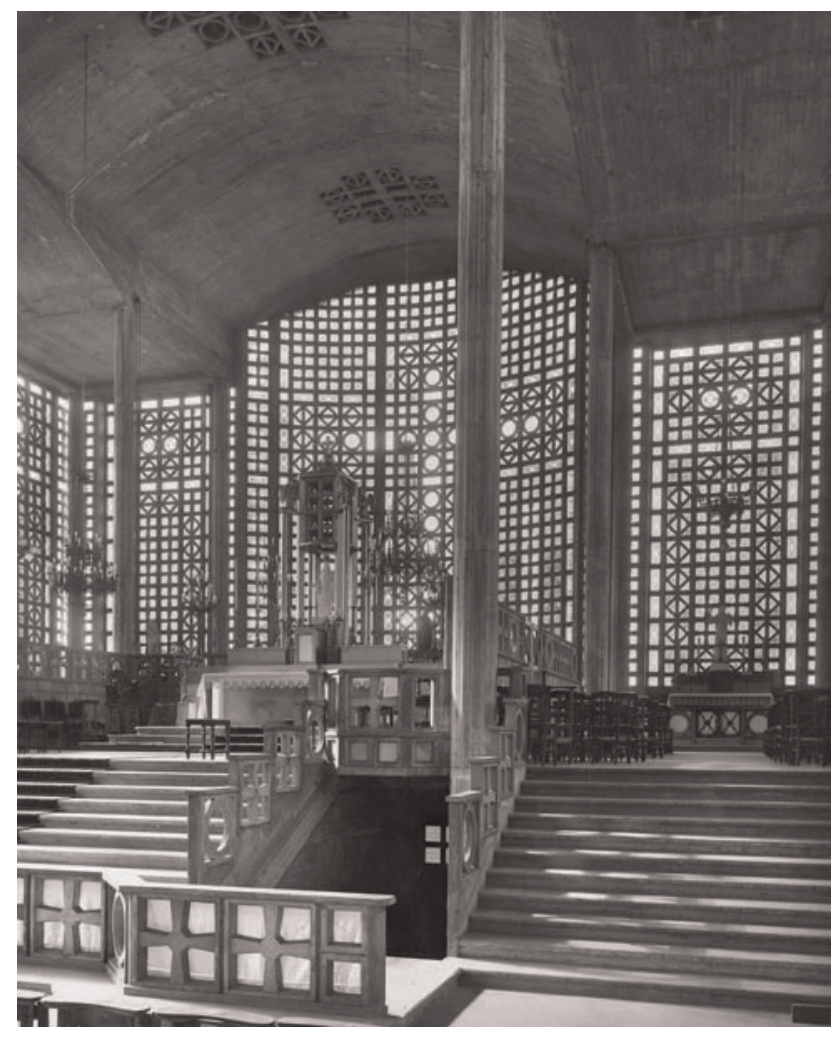

Figure 19 Perret Frères, Notre-Dame du Raincy, Le Raincy, France, 1923, balustrade and altar (photo: Chevojon, dossier 535 AP 653/2, document CNAM-22-01-O, Fonds Auguste Perret et Perret Frères, Centre d'Archives d'Architecture du XX Siècle, Paris; CNAM/SIAF/CAPA/ Archives d'Architecture du XXe Siècle/Auguste Perret/UFSE/SAIF/2019).

barracks and Nissen huts converted into makeshift churches for towns such as Soyécourt, Brie, Fonches, Estrées-Deniécourt, Lihons, Chaulnes (all in the Somme), and NeuvilleVitasse (in the Pas-de-Calais) (Figure 21). Churches made of recycled Nissen huts featured clerestories that allowed natural light to trickle in from the center of their barrel vaults. Wooden crosses and stout steeples with bells were added to advertise the religious function of these otherwise anonymous, industrial-looking buildings.

To meet their budget for Notre-Dame du Raincy, the Perrets employed building practices identical to those the Allied armies had used during the war. They reduced costs significantly by having the church's perforated concrete blocks prefabricated in large batches. As the French building industry struggled with the skyrocketing material and labor costs triggered by the war, such mass-production and prefabrication construction practices became widespread. Notions of efficient industrial manufacturing caught on as the need to generate ever greater quantities of war supplies rose in France, and as new machines and systems allowed. Réjean Legault argues that Notre-Dame du Raincy demonstrates the Perrets' appropriation of wartime and postwar emphases on faster,

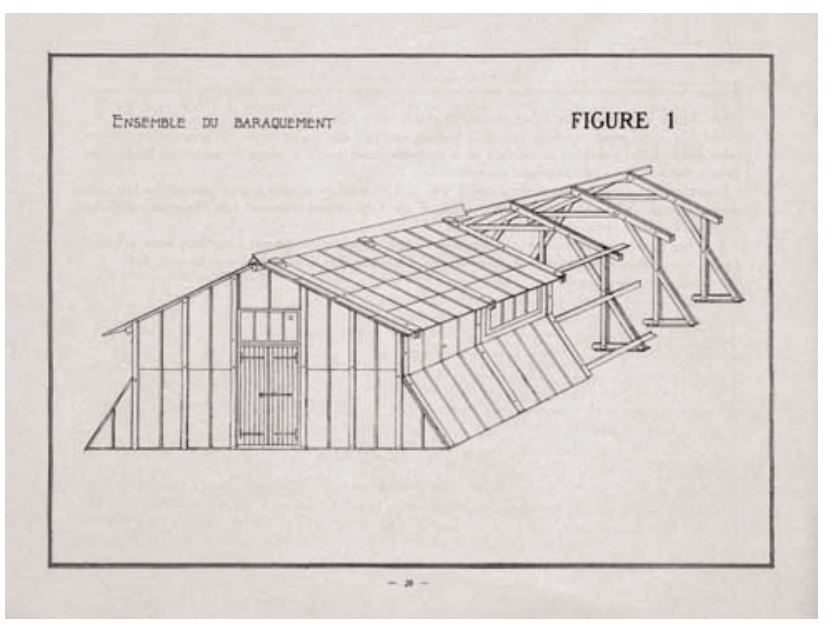

Figure 20 Adrian barrack (drawing by unknown artist; Ministère le la Guerre, Baraquement système Adrian [Paris: Draeger, n.d.], 20).

more streamlined, cheaper methods of production. ${ }^{90}$ Frederick Taylor's ideas on the scientific organization of labor (or, as translated by the chemist Henri Le Châtelier, the organisation scientifique du travail) made significant inroads in France during the war years. ${ }^{91}$

The Perret archives contain limited information about Notre-Dame du Raincy's construction, but they do reveal the involvement of a company called Les Chantiers de Villemonble, headquartered near Le Raincy. The Perrets subcontracted the task of manufacturing the perforated concrete blocks to this company. ${ }^{92}$ On its letterhead, Les Chantiers de Villemonble touted its services as enabling the "rapid and economical reconstruction of the devastated regions," expanses of which stood just east and northeast of the company's offices. It specialized in manufacturing component pieces for construction, including pipes and cladding tiles made of matières agglomérées - that is, glued and pressed materials of cement and other powderlike substances. ${ }^{93}$ Thus, the methods and materials used for the Perrets' church were the same as those used for many buildings in the war zone.

Notre-Dame du Raincy, though not located in an area wracked by war, was nonetheless loosely affiliated with a set of projects designed for those regions. ${ }^{94}$ Those projects included the Perrets' fiber-cement church for the 1916 Société de Saint-Jean competition, Thomas's wooden kit-of-parts church for La cité reconstituée, the temporary churches made of former military huts, and buildings— such as those from Les Chantiers de Villemonble-made of mass-produced parts and dependent on the latest construction techniques. Thus, in addition to commemorating the war and its toll, Notre-Dame du Raincy was directly associated with a range of lightweight, industrialized designs and practices developed to help wage that war as well as to rebuild those edifices it had destroyed. 


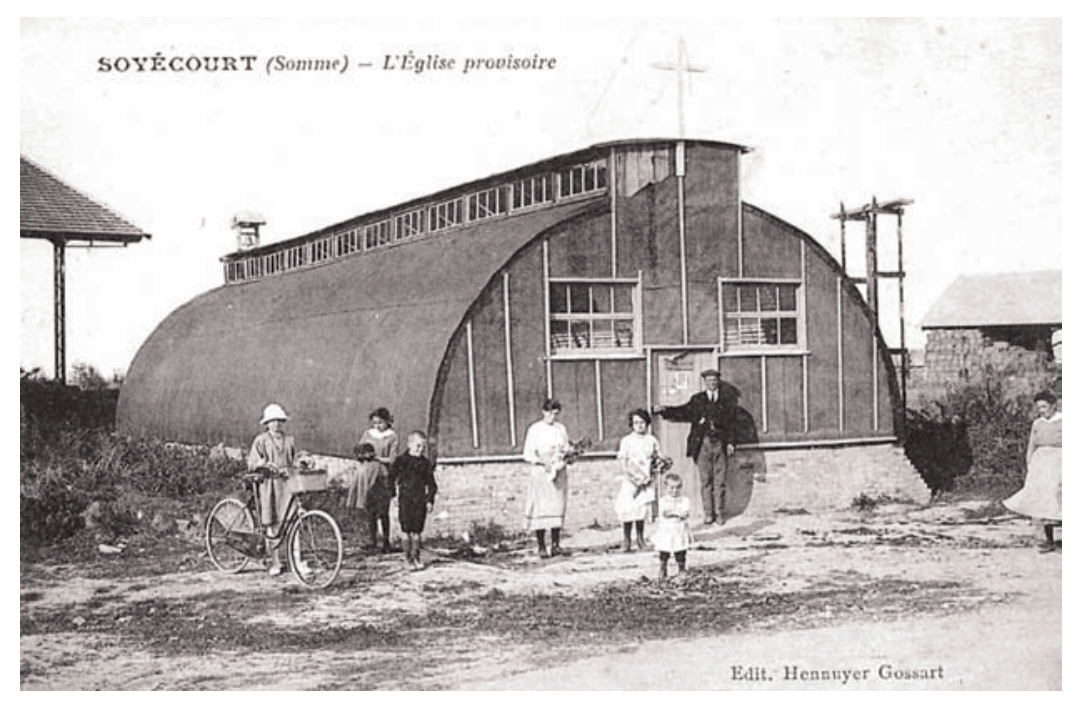

Figure 21 Provisional church in Soyécourt in the Somme, France, ca. 1918 (postcard, author's collection).

\section{Conclusion}

Notre-Dame du Raincy's chapel of the dead and its stained glass window representing the Taxis of the Marne are its two most explicit references to the war, but these hint at other links on which observers in the 1920s often commented. Jamot saw a deliberate reference to medieval French lanterns of the dead in the belfry's massing. Another writer noted that "the church of Le Raincy commemorates the victory of Ourcq and some people say: 'her steeple recalls anti-aircraft canons!' "95 Neither Auguste nor Gustave Perret fought on the front lines, though both designed temporary structures for the war zone. Technical innovations developed for those buildings found their way into the design of Notre-Dame du Raincy. In sum, many connections to World War I appeared within the iconography, materials, and building methods that formed this project.

A sharp distinction nonetheless separates the building's explicit war references from its more indirect or unintentional ones. While the chapel of the dead, Denis's window, and the lantern of the dead-cum-bell tower align with conservative French notions of commemoration, the materials, finishes (or lack thereof), and building processes used here do not. This discrepancy echoes disagreements in 1920s France about the consequences and meanings of the war.

Historians have shown how reactionary ideologies made significant inroads in France (and other parts of Europe) following World War I, as chauvinistic eulogies to dead soldiers were accompanied by a resurgence in traditional notions of value and order. ${ }^{96}$ Art was not impervious to this trend. French artists who, prior to the war, had pioneered groundbreaking and controversial forms of representation suddenly pivoted away from these during the late 1910s and early 1920s, embracing in their stead a return to figural representation and overtures to the classical past. ${ }^{97}$ Patriotism, nationalism, and a disdain for the disruptions of modernity lurked beneath the surface of such work, which heeded poet Jean Cocteau's call for an aesthetic rappel à l'ordre (return to order). ${ }^{98}$ In its more overt symbolism, Notre-Dame du Raincy was part of this trend. Its war-themed imagery affirmed mainstream views of the period, asserting France's status as a superior, singular culture with a long history deserving of revival and respect. ${ }^{99}$

Yet the church contains two features widely viewed as a threat to French conservatism, both outgrowths of the war, both widespread in its wake: its concrete construction and its standardized, mass-produced components. During the war, many French citizens viewed these as necessary evils justified by extenuating circumstances. Like the war itself, raw concrete buildings and industrialized construction processes were widely understood as exceptional, not normal, occurrences. ${ }^{100}$ With the armistice, progressive reformers (including technocrats such as Raoul Dautry, Louis Loucheur, and Édouard Herriot) expressed support for these innovations as necessary for the modernization of architecture and construction. ${ }^{101}$ They met stiff resistance from opponents who heaped scorn on standardized modular construction and on reinforced concrete's use for significant architecture, seeing both as incongruous with French values. ${ }^{102}$ Their adoption, it was feared, would displace traditional materials and procedures regarded by many as integral to French architectural culture and identity. ${ }^{103}$ In short, Notre-Dame du Raincy's materials and means of construction endeared the church to those who embraced novelty over tradition. ${ }^{104}$

Reform-minded French progressives were also forced to contend with the fact that many of their compatriots associated reinforced concrete and standardization with Germany, whose people the French had often branded as mechanistic, ruthless, and uncivilized. ${ }^{105}$ After the war, there was little sympathy in France for ideas perceived as German. Auguste Perret and other champions of concrete architecture sought 
to bypass this bias by insisting that reinforced concrete was a French invention. ${ }^{106}$ The truth, however, is more complex. Various kinds of concrete or cement strengthened with metal emerged in several places-including France-around the middle of the nineteenth century, and German engineers and builders made significant contributions to these developments. ${ }^{107}$ The Great War triggered further advances in concrete construction on both sides of the front, and French military engineers in particular learned much from the successes of their rivals. Thus, although Notre-Dame du Raincy honors French losses through imagery rife with nationalistic overtones, the church is constituted of a material and mode of construction emblematic of France's technical debt to Germany and other foreign countries.

The church therefore straddled both sides of a debate that coursed through 1920s France, epitomizing its citizens' failure to agree on how best to conceptualize and represent the war and its consequences. On the one hand, Notre-Dame du Raincy's iconography aligned with jingoistic popular ideologies that cast the war as a justified and ultimately triumphant fight waged by good against evil. On the other, the church's more oblique references to the war conveyed its darker legacies, such as the scarcity of resources, as well as its technological innovations. The latter cut across state boundaries and challenged the then-conventional view that France could heal properly only by casting off foreign influence and the war's unsettling technical by-products. By having a foot on each side of the debate, Notre-Dame du Raincy called both into question.

Etien Santiago is an architectural historian, educator, and licensed architect. He is completing a dissertation at Harvard University on how the cultural and intellectual contexts of World War I shaped architects' appropriation of innovative military construction techniques and led them toward creating new forms of affordable housing. etsant@iu.edu

\section{Notes}

1. Like Bourdelle, Denis had collaborated with Auguste Perret on the 191113 Thêatre des Champs-Élysées in Paris. Perret had originally asked the Italian futurist painter Gino Severini to propose designs for Notre-Dame du Raincy's stained glass. Severini, a member of the Art et Liberté group of Parisian artists that Perret cofounded in 1916, embarked on this task in the summer of 1922, but Denis later replaced him. Gino Severini to Auguste Perret, 23 July 1922, dossier 535 AP 560, Fonds Auguste Perret et Perret Frères, Centre d'Archives d'Architecture du XX $X^{\mathrm{e}}$ Siècle, Paris (hereafter Fonds Perret, CAA); Giovanni Fanelli and Roberto Gargiani, Perret e Le Corbusier: Confronti (Rome: Laterza, 1990), 80.

2. Véronique David, "De l'espoir retrouvé et des vitraux du Raincy: Une collaboration d'artistes et de personnalités d'exception," in Un patrimoine de lumière, 1830-2000: Verrières des Hauts-de-Seine, Seine-Saint-Denis, Val-deMarne, ed. Laurence de Finance (Paris: Monum-Éditions du Patrimoine, 2003), 274-85.
3. Joseph Abram, "An Unusual Organisation of Production: The Building Firm of the Perret Brothers, 1897-1954," Construction History 3 (1987), 75-93.

4. Joseph Abram, Auguste Perret (Paris: Infolio, 2010), 27.

5. Peter Collins, Concrete: The Vision of a New Architecture (Montreal: McGillQueen's University Press, 2004), 240-46; Peter Collins, "The Contribution of Auguste Perret," 1, box 17, folder 2, Peter Collins Papers (collection 64), Canadian Architecture Collection, McGill University. See also Abram, Auguste Perret, 96.

6. J. Marrast and J. Droz, plans, sections, and elevations of the church of Saint-Louis de Vincennes, 1914-20, dossier 535 AP 555/1, Fonds Perret, CAA.

7. Roberto Gargiani and Giovanni Fanelli, Auguste Perret (Rome: Laterza, 1991), 45-48. Collins has pointed out similarities between these projects, but without going into much detail. See Collins, Concrete, 242. See also Joseph Abram, A. et G. Perret, une monographie (Nancy: LHAC/BRA, 1989), cited in Réjean Legault, "L'appareil de l'architecture moderne: New Materials and Architectural Modernity in France, 1889-1934" (PhD diss., Massachusetts Institute of Technology, 1997), 147.

8. See Henry-Russell Hitchcock, Architecture: Nineteenth and Twentieth Centuries (New York: Penguin Books, 1977), 425-26; Leonardo Benevolo, History of Modern Architecture, vol. 1, Tradition of Modern Architecture, trans. H. J. Landry (Cambridge, Mass.: MIT Press, 1971), 329-31; Ernesto N. Rogers, Auguste Perret (Milan: Il Balcone, 1955), 33-39.

9. See Paul Jamot, A. G. Perret et l'architecture du béton armé (Paris: G. Vanoest, 1927), 50; André Le Donné, Notre-Dame-du-Raincy (Paris: Éditions du Cerf, 1947), 4.

10. Legault, "L'appareil de l'architecture moderne," 147-60; Simon Texier, "Les matériaux ou les parures du béton," in Églises parisiennes du XX" siècle: Architecture et décor, ed. Simon Texier (Paris: Action Artistique de la Ville de Paris, 1996), 72-82; Simon Texier, "Église Notre-Dame-de-la-Consolation, Le Raincy," in Les Frères Perret, l'auvre complète: Les archives d'Auguste Perret (1874-1954) et Gustave Perret (1876-1952), arcbitectes-entrepreneurs, ed. Maurice Culot, David Peyceré, and Gilles Ragot (Paris: Norma, 2000), 125-26; Andrew Saint, "Notre-Dame du Raincy," Architects' fournal 7, no. 193 (1991), 26-43; Karla Britton, "The Economy of Construction: Ecclesiastical Architecture," in Auguste Perret (New York: Phaidon, 2001), 77-103; Christian Freigang, Auguste Perret, die Architekturdebatte und die "Konservative Revolution" in Frankreich 1900-1930 (Munich: Deutscher Kunstverlag, 2003), 235-77.

11. Louis Gillet, "Saint-Taxi," Le Gaulois, 18 June 1923, 1; Antoine Le Bas, "Notre-Dame du Raincy (Seine-Saint-Denis), chef d'œuvre des chapelles de la banlieue," In Situ, no. 11 (2011), 3.

12. A. Fulcran, "L'église du Raincy," La Croix, 7 Sept. 1922, dossier 535 AP 550, Fonds Perret, CAA. See also P. Dolley, "La guerre mondiale par M. J. Champagnol," Bulletin Société historique du Raincy et des environs, no. 3 (1 Jan. 1931), 4.

13. Henri Carré, La véritable histoire des taxis de la Marne (6, 7 et 8 septembre 1914) (Paris: Librairie Chapelot, 1921). The son of Notre-Dame du Raincy's anonymous major benefactor died in this battle. Le Bas, "Notre-Dame du Raincy," 3.

14. Cordelia Bonal, "Non, les taxis de la Marne n'ont pas sauvé Paris," Libération, 3 Aug. 2014.

15. Fulcran, "Léglise du Raincy."

16. Gillet, "Saint-Taxi," 1; Yvanhoé Rambosson, "Une basilique moderne," L'Illustration, 23 June 1923, reprinted in Union paroissiale du Raincy, 9, dossier 535 AP 414/02, Fonds Perret, CAA.

17. Patrick Fridenson, "Introduction: A New View of France at War," in The French Home Front 1914-1918, ed. Patrick Fridenson (Providence, R.I.: Berg, 1992), 2.

18. The current knight statue is most likely a modern replacement for one placed in the same location as early as 1927 . See Jamot, A. G. Perret, plate XXIV. 
19. Peter Doyle, World War I in 100 Objects (New York: Penguin, 2014), 46. 20. See Antoine Prost, "Le sens de la guerre: Les monuments aux morts de 1914-1918 en France," in Comment (se) sortir de la Grande Guerre? Regards sur quelques pays "vainqueurs": La Belgique, la France et la Grande-Bretagne, ed. Stéphanie Claisse and Thierry Lemoine (Paris: L'Harmattan, 2005), 11-33. 21. Antoine Prost, "Monuments to the Dead," in Realms of Memory: The Construction of the French Past, vol. 2, Traditions, ed. Pierre Nora and Lawrence D. Kritzman, trans. Arthur Goldhammer (New York: Columbia University Press, 1997), 307-8.

22. Prost, 309.

23. The 1905 French law on the separation of church and state banned the use of religious symbols on public monuments. Although funerary monuments were exempted from this rule, a monument had to be located within a cemetery to qualify for the exemption. Some Catholics were upset that French Great War memorials sited in prominent urban squares could not display Christian crosses or other religious iconography. Consequently, in 1924, the government reversed course on this matter. Prost, "Le sens de la guerre," 13-15.

24. See Prost, 19, 32.

25. A. Goissaud, "Une église en béton armé," La Construction moderne 39, nos. 254-56 (2 Mar. 1924), 185.

26. Jamot, A. G. Perret, 54. Unless otherwise noted, all translations are my own.

27. Eugène-Emmanuel Viollet-le-Duc, "Lanterne des morts," in Dictionnaire raisonné de l'architecture française du XI au XVI siècle, vol. 6 (Paris: B. Bancé, 1863), 154-60. As a child, Auguste Perret consulted his father's collection of Viollet-le-Duc's books. Abram, "Unusual Organisation of Production," 80.

28. Anne Biraben, Les cimetières militaires en France (Paris: L'Harmattan, 2015), 142.

29. "Ville de Nice: Monument du souvenir," Compte rendu mensuel des travaux de la Société des artistes français, no. 213 (June-Sept. 1919), 48.

30. "Le Monument aux morts de Notre-Dame-de-Lorette," L'Illustration, 1 Apr. 1922, 293-94; "Le Monument commémoratif de Lorette," L'Arcbitecture 33, no. 16 (15 Sept. 1920), 216.

31. "Le Fanal de Lorette," Le Figaro, 4 July 1921, 1.

32. Biraben, Les cimetières militaires en France, 143.

33. "Concours pour l'érection de l'Ossuaire de Douaumont près de Verdun," Art et Décoration: Chronique 42 (Sept. 1922), 5; Simon Texier, Les architectes de la mémoire (Paris: Huitième Jour, 2007), 26-27.

34. See Antoine Prost, "Verdun," in Realms of Memory: The Construction of the French Past, vol. 3, Symbols, ed. Pierre Nora and Lawrence D. Kritzman, trans. Arthur Goldhammer (New York: Columbia University Press, 1998), 387-94. 35. Ch. Risler, "Concours publics," L'Architecture 33 (1920), 153-55; Philippe Rivé, Monuments de mémoire: Les monuments aux morts de la Première Guerre mondiale (Paris: La Mission, 1991), 108; Stéphanie Tison, Comment sortir de la guerre? Deuil, mémoire et traumatisme (1870-1940) (Rennes: Presses Universitaires de Rennes, 2011), 196.

36. Cordonnier, an influential architect from northern France entrusted with multiple responsibilities at the national level, served on the competition jury. Risler, "Concours publics," 153. See also Jean-Pierre Blin, "Les églises de la reconstruction, entre éclectisme et modernité," in La Grande Reconstruction: Reconstruire le Pas-de-Calais après la Grande Guerre, ed. Éric Bussière, Patrice Marcilloux, and Denis Varaschin (Arras: Archives Départementales du Pas-de-Calais, 2002), 325; Richard Klein, "Régionalismes et reconstruction," in Bussière et al., La Grande Reconstruction, 319; Texier, Les architectes de la mémoire, 37-38.

37. Fulcran, "L'église du Raincy."

38. Texier, Les architectes de la mémoire, 45; Jay Winter, Sites of Memory, Sites of Mourning: The Great War in European Cultural History (Cambridge: Cambridge University Press, 1995), 93, 97-98, 207.
39. "Présentation: Description du monument," Mémorial des Batailles de la Marne 1914-1918 à Dormans, http://www.memorialdormans14-18.com/ presentation/description-du-monument (accessed 20 Aug. 2017).

40. Pierre-Yves Caillault, "Ossuaire de Douaumont: La restoration de l'édifice," in L'Ossuaire de Douaumont cathédrale de la Grande Guerre, ed. Stéphanie Quantin et al. (Ars-sur-Moselle: Serge Domini, 2015), 128-35.

41. "La chapelle Notre-Dame de Lorette: Les origines du sanctuaire dédié à Notre-Dame de Lorette," Association du Monument de Notre-Dame de Lorette, http://association-du-monument-de-notre-dame-de-lorette.e-monsite. com/pages/la-basilique-notre-dame-de-lorette.html (accessed 20 Aug. 2017). 42. See Roberto Gargiani, Auguste Perret 1874-1954: Teoria e opere (Milan: Electa, 1993).

43. As Peter Collins has noted, "In the present-day it is difficult to realize the scandal created by the decision to build a church in such a way that its reinforced concrete skeleton, as well as its prefabricated infill, would not be coated with so-called 'noble' construction materials." Peter Collins, "Le centenaire d'Auguste Perret," undated, 13, box 17, folder 2, Peter Collins Papers (collection 64), Canadian Architecture Collection, McGill University.

44. Ventre was a principal actor in the régionaliste architectural movement in France, which sought to rebuild houses and towns destroyed by war in the spirit of traditional regional structures. Franck Viltart, "Naissance d'un patrimoine: Les projets de classement des ruines, vestiges et souvenirs de guerre (1915-1918)," In Situ, no. 23 (2014), 16-40. See also Jean-Claude Vigato, "L'architecture du régionalisme: Les origines du débat (1900-1950)," in Les Trois Reconstructions 1919 . . 1940 . . 1945 (Paris: Institut Français d'Architecture, 1983), 34.

45. Gabriel Boissy, "Une féerie architecturale," L'Intransigeant, 9 July 1923. 46. The memorial was partially finished four years later and was finally inaugurated in 1938. Texier, Les architectes de la mémoire, 20.

47. "Le Monument commémoratif de l'intervention américaine," L'Illustration, 2 July 1921, 5; Claire Steimer, “'À la gloire des Américains’: Le monument commémoratif du Verdon-sur-Mer," In Situ, no. 25 (2014), 5-10.

48. Steimer, “'À la gloire des Américains,'” 11; Gabriel Boissy, "Une colonne de lumière," L'Intransigeant, 20 May 1923. The first issue of L'Architecture vivante, edited by Jean Badovici, appeared in 1923; it opened with a report about the recently completed Notre-Dame du Raincy, followed by another on the Monument aux Américains, construction of which had just commenced. Jean Badovici, "Entretiens sur l'architecture vivante," L'Architecture vivante, no. 1 (1923), 12-18.

49. "M. Millerand à Verdun, inauguration du monument de la 'Tranchée des baïonnettes,'” Le Bulletin meusieun, 12 Dec. 1920, 1; André Fage, "La véritable histoire de la Tranchée des baïonnettes dont M. Millerand va inaugurer le monument," Le Petit fournal, 3 Dec. 1920, 1; A Fulcran, "Le Salon," La Croix, 8 Dec. 1921.

50. Léandre Vaillat, "La Tranchée des baïonnettes," Le Figaro, 27 June 1920, 1.

51. Dominique Barjot, "Entreprises et entrepreneurs face à l'effort de guerre: Electricité et travaux publics (1914-1918)," in Deux guerres totales: 1914-1918, 1939-1945, ed. Dominique Barjot (Paris: Economica, 2012), 195; Dominique Barjot, "Innovation et travaux publics en France (1840-1939)," Histoire, économie et société 8, no. 3 (1989), 407; M. N. Bussell, "The Era of Proprietary Reinforcing Systems," in Early Reinforced Concrete, ed. Frank Newby (Aldershot, England: Ashgate, 2001), 215; William B. Parsons, The American Engineers in France (New York: D. Appleton, 1920), 318. This new enthusiasm for concrete was impeded by France's wartime drop in coal production, since coal was necessary to make cement. George B. Ford, "The Facts on the Devastation and the Present Reconstruction Efforts in France," Engineering News-Record 82, no. 5 (30 Jan. 1919), 222.

52. Keith Mallory and Arvid Ottar, The Architecture of War (New York: Pantheon Books, 1973), 35-53; Peter Oldham, Pill Boxes on the Western Front: 
A Guide to the Design, Construction and Use of Concrete Pill Boxes 1914-1918 (London: Leo Cooper, 1995).

53. Vaillat, "La Tranchée des baïonnettes," 1.

54. Jean-Charles Cappronnier, "Penser la reconstruction en 1917," in Reconstructions en Picardie après 1918 (Paris: Réunion des Musées Nationaux, 2000), 61-62; Viltart, "Naissance d'un patrimoine," 19-26; Léandre Vaillat, La maison des pays de France, les provinces dévastées: Flandre, Artois, Picardie, Ile-deFrance, Champagne, Lorraine, Alsace (Paris: Flammarion, 1917), 14; Jacques Lucan, "Chronique d'années de guerre," Architecture, mouvement, continuité: Bulletin de la Société des architectes diplômés par le gouvernement, no. 44 (Feb. 1978), 71.

55. Muriel Harris, "A Concrete Church in France," Manchester Guardian, 2 Mar. 1926, 1, dossier 535 AP 550, Fonds Perret, CAA.

56. Muriel Harris, "Concrete Takes New Form in a French Church," New York Times Magazine, 18 Apr. 1926, 1, dossier 535 AP 550, Fonds Perret, CAA.

57. According to Harris, "There is no doubt about the feeling conveyed by the Church of the Ourcq [Notre-Dame du Raincy]. The people who built it, the workmen who handled the concrete, all knew literally the meaning of war." Harris, 1.

58. Léandre Vaillat, "Du ciment armé, son esthétique," Les Arts français, no. 20 (1918), 149-64; Adrien Paul, "De la pierre à travers les âges: Les produits susceptibles de la remplacer," in Congrès technique international de la maçonnerie et du béton armé (Paris: Chambre Syndicale des Entrepreneurs de Maçonnerie, Ciments et Béton Armé de la Ville de Paris et du Département de la Seine, 1928), 5; Henri-Marcel Magne, "L'architecture et les matériaux nouveaux," Art et Décoration 36 (1919), 86.

59. Charles-Auguste Roux, "Le problème de la reconstruction dans les régions dévastées," La France au travail 1, no. 1 (Dec. 1916), 5.

60. According to Britton, "In choosing concrete as the material for a church, therefore, Perret was not only breaking with the tradition of using expensive material for significant public buildings, he was also employing the local architectural vernacular." Britton, "Economy of Construction," 87-88.

61. Britton, 88 .

62. See George B. Ford, Out of the Ruins (New York: Century, 1919).

63. André Guillerme, Hélène Vacher, and Kinda Fares, "Le Front de l'industrialisation de la construction 1915-1920," Les Cabiers de la recherche architecturale et urbaine 28 (2013), 43-44; Parsons, American Engineers in France, 153. 64. A.V., "Du charbon! Du charbon!", Le Gaulois, 28 Jan. 1917, 2; Georges Ohnet, Fournal d'un bourgeois de Paris pendant la guerre de 1914 (Paris: Société d'Éditions Littéraires \& Artistiques, 1914), 2006-8.

65. As completed, Notre-Dame du Raincy contains only small quantities of wood, but during construction, large amounts were needed for the concrete formwork. Given the tight budget, the Perrets reused formwork from another project. Auguste Perret, "Notes sur l'église du Raincy," undated, 3, dossier 535 AP 414/2, Fonds Perret, CAA. This other contemporary project was likely the renovation of the Société Marseillaise du Crédit bank in Paris, since the Perret Frères accounting book lists a charge on 28 March 1922 for the transportation of material from the "chantier de Marseille" to Le Raincy. Livre journalier des dépenses, 1920-1925, dossier 535 AP 583, Fonds Perret, CAA.

66. Marrikka Trotter deserves credit for this observation, which she articulated in a conversation with me.

67. See, for example, Ford, Out of the Ruins.

68. Olivier Rigaud and Marc Bédarida, Reims: Reconstruction 1920-1930 (Reims: Ville de Reims, 1988), 3.

69. André Ventre, drawing of "Blockhaus allemand dans le clocher," series 0080/107/1004, document 015277, Médiathèque de l'Architecture et du Patrimoine, Paris.

70. Jean-Charles Cappronnier, "Les églises reconstruites après la Grande Guerre,” in Reconstructions en Picardie après 1918, 153-54. See also Cappronnier,
"Penser la reconstruction en 1917," 53-54. The Allies were never able to desecrate German buildings, primarily because the initial German invasion advanced so deeply into historically French and Belgian territories that throughout the remainder of the war the Allies were unable to push the front line far enough in the opposite direction to reach historically Germanic lands. Allied troops had made only limited headway toward that goal by the time the armistice was signed, thus Germany was spared any architecture-directed retribution by the Allies.

71. See, for instance, A. Besnard, "Faut-il restaurer les monuments saccagés par les vandales?," L'Architecture (Apr. 1916), 61-64. See also Joseph Dassonville, Pour relever les ruines: Maisons et mobilier, villes et villages, églises et mobilier sacré, le monument aux morts, la catbédrale (Paris: Librairie Académique Perrin, 1919), 169-236.

72. Cappronnier, "Penser la reconstruction en 1917," 50.

73. See Abel Fabre, "La reconstruction des églises dévastées," La Vie \& les Arts liturgiques 2, no. 20 (Oct. 1915-Feb. 1916), 305-23; M.-C. Poinsot, "Reims, ossuaire national," Le Petit Messager des arts et des artistes, et des industries d'art, no. 17 (1 Oct. 1915), 1-2; Camille Flammarion, "Reims, ossuaire national," Le Petit Messager des arts et des artistes, et des industries d'art, no. 18 (15 Oct. 1915), 2; Paul Léon, La renaissance des ruines: Maisons, monuments (Paris: H. Laurens, 1918), 78-79.

74. Auguste Perret, "Enquête sur la conservation et l'entretien des monuments historiques," 1, unpublished manuscript, 2 Jan. 1936, dossier 535 AP 548, Fonds Perret, CAA; Hubert Lempereur, "Ruines," in Encyclopédie Perret, ed. Jean-Louis Cohen, Joseph Abram, and Guy Lambert (Paris: MonumÉditions du Patrimoine, 2002), 134.

75. Comité Catholique de Propagande Française à l'Étranger, "La Société de Saint-Jean," in Almanach catholique pour 1920 (Paris: Bloud et Gay, 1920), 310. 76. The competition entries were exhibited in the Pavillon de Marsan at the Louvre in Paris. Fabre, "La reconstruction des églises dévastées," 305-23. See also Texier, "Les matériaux ou les parures du béton," 74; Legault, "L'appareil de l'architecture moderne," 157; Simon Texier, "Églises," in Cohen et al., Encyclopédie Perret, 139; André Michel, "Projet d'abris provisoires pour les paroisses dévastées," Zournal des débats, 17 Feb. 1916, 3.

77. Fabre, "La reconstruction des églises dévastées," 317. According to Fabre, the Perrets planned to develop an alternative design made entirely of concrete without any metal reinforcement. A French company called La Construction Manufacturée sold demountable pavilions with panels made of fiber cementakin to asbestos - surrounding wooden structural skeletons. "La Construction manufacturée," L'Humanité, 19 July 1914, 2. La Construction Manufacturée later participated in the La cité reconstituée exhibition, described below.

78. Cappronnier, "Penser la reconstruction en 1917," 50-51; Association Générale des Hygiénistes et Techniciens Municipaux, Exposition de la Cité reconstituée: Esthétique et bygiène, Salle du jeu de paume \& terrasse des Tuileries (25 mai-15 août 1916) (Paris: Imprimerie Centrale de la Bourse, 1917).

79. Georges Espitallier, "Constructions civiles: La reconstruction dans les régions envahies," Le Génie civil 70, no. 20 (19 May 1917), 323; "Une visite à la Cité reconstituée," Le Monde illustrée 60, no. 3053 (24 June 1916), 420; Charles du Bus, "Deux aspects de l'art urbain: II. Vers la cité prochaine," Gazette des beaux arts, no. 688 (Aug. 1916), 384-85. Thomas, a student of Baudot, had already designed the Parisian church of Saint-Joseph des Épinettes. Built in 1909-10, it features a concealed concrete structure. Texier, "Les matériaux ou les parures du béton," 68.

80. See also Cappronnier, "Les églises reconstruites," 157.

81. Comité Catholique de Propagande Française à l'Étranger, "Limagerie religieuse," in Almanach catholique pour 1920, 312.

82. Charles-Édouard Jeanneret to Max Du Bois, 17 April 1916, transcribed in Max Du Bois, "Manuscrit original d'un ouvrage sur Le Corbusier," document E1-19-185, Fondation Le Corbusier, Paris.

83. Georges Espitallier, "Notes sur les constructions économiques et démontables," Bulletin de la Société d'encouragement pour l'industrie nationale 
114 (May-June 1915), 535-36; Georges Espitallier, "La Cité reconstituée," Bulletin de la Société d'encouragement pour l'industrie nationale 115 (Sept.-Oct. 1916), 314-15; Espitallier, "Constructions civiles," 306.

84. Guy Lambert, "Repères biographiques," in Cohen et al., Encyclopédie Perret, 17.

85. Pierre Vago, "Perret," L'Architecture d'Aujourd'bui 3, no. 7 (Oct. 1932), 16. 86. Guillerme et al., "Le Front de l'industrialisation de la construction," 37. 87. Guillerme et al., 37-56.

88. Mallory and Ottar, Architecture of War, 75-81.

89. Guillerme et al., "Le Front de l'industrialisation de la construction," 53; Philippe Nivet, Les réfugiés français de la Grande Guerre 1914-1920: Les "boches du nord" (Paris: Economica, 2004), 252; Cappronnier, "Les églises reconstruites," 156; David de Sousa, La reconstruction et sa mémoire dans les villages de la Somme (1918-1932) (Woignarue: Vague Verte, 2001), 35-44, 54-56.

90. Legault, "L'appareil de l'architecture moderne," 158-60.

91. Georges Hersent, Une politique de la construction après la guerre: Travaux publics et bâtiment (Paris: Payot, 1919), 213. See also Victor Cambon, ÉtatsUnis, France (Paris: P. Roger, 1917), chap. 8; Aimée Moutet, "La Première Guerre mondiale et le taylorisme," in Le Taylorisme, ed. Maurice de Montmollin and Olivier Pastré (Paris: La Découverte, 1984), 67-81; Olivier Cinquealbre, "France 1913-1925, Taylor dans le bâtiment: Une idée qui fait son chemin," in Architecture et industrie: Passé et avenir d'un mariage de raison (Paris: Centre Georges Pompidou, 1983), 198-206; Gerd Hardach, "Industrial Mobilization in 1914-1918: Production, Planning, and Ideology," in Fridenson, The French Home Front, 83-84.

92. Les Chantiers de Villemonble to Perret Frères, undated and 2-3 Aug. 1922, dossier 535 AP 414/2, Fonds Perret, CAA.

93. Les Chantiers de Villemonble to Perret Frères, undated and 2-3 Aug. 1922.

94. In 1922, Fabre opined that Notre-Dame du Raincy was a paragon of economic church construction, an example for rebuilding churches throughout the devastated regions of France. Fulcran, "L'église du Raincy."

95. "La nouvelle église du Raincy," Bulletin de Gagny, n.d., reprinted in the Union paroissiale du Raincy, 11-12.

96. See Charles Maier, Recasting Bourgeois Europe: Stabilization in France, Germany, and Italy in the Decade after World War I (Princeton, N.J.: Princeton University Press, 1975); Mark Mazower, Dark Continent: Europe's Twentieth Century (New York: Vintage Books, 1998); Winter, Sites of Memory; J. M. Winter, "Catastrophe and Culture: Recent Trends in the Historiography of the First World War," Fournal of Modern History 64, no. 3 (Sept. 1992), 525-32.

97. Kenneth E. Silver, Esprit de Corps: The Art of the Parisian Avant-Garde and the First World War (Princeton, N.J.: Princeton University Press, 1989).

98. Silver. See also Benjamin Buchloh, "Figures of Authority, Ciphers of Regression: Notes on the Return of Representation in European Painting," October 16 (Spring 1981), 39-68.

99. On this topic, see Freigang, Auguste Perret.

100. See, for example, Louis Jardin, "Les arts mécaniques et l'architecture de demain," Le Bâtiment: Fournal des travaux publics et particuliers 53, nos. 95-96 (26-30 Nov. 1916).

101. Remi Baudouï, Raoul Dautry 1880-1951: Le technocrate de la République (Paris: Balland, 1992); Stephen Douglas Carls, Louis Loucheur and the Shaping of Modern France, 1916-1931 (Baton Rouge: Louisiana State University Press, 1993); Gérard Chauvy, Édouard Herriot, 1872-1957, et le radicalisme triomphant (Lyon: Lugd, 1996).

102. "À propos de la réponse de M. René Prinet," supplement no. 11, Le Petit Messager des arts et des artistes, et des industries d'art, no. 17 (1 Oct. 1915), 1; V. Sabouret, "Grandes églises voûtées en béton armé," Le Génie civil, 5 Jan. 1924, 1, dossier 535 AP 555, Fonds Perret, CAA.

103. Vaillat, "Du ciment armé," 151.

104. In 1932, Le Corbusier wrote about Notre-Dame du Raincy: "The inside, which is the result of designing in section, is splendid. This section corresponds to the conquests of reinforced concrete, administered by a sage, a cunning and bold man. [Is it the] section of a church? Not at all! [It is the] section of any industrial or sacred vessel, whose economy has been pushed to the limit. Here is Auguste Perret, it is him, truly him, where we admire him without reserve and say: Master! The outside in front [of the building] is the façade of a church with its steeple. [Chalk it up to a] dialectic, ritual, liturgy, anything that you want. Yet this magnificent church possesses a face that is a mask. It is thanks to this mask that one day Auguste Perret will be admitted to the Institute [of France, or the Academy]; but it is the section of the vessel that will delay this event." Le Corbusier, "Perret," L'Arcbitecture d'Aujourd'bui 3, no. 7 (Oct. 1932), 7-9.

105. Early twentieth-century French critics of reinforced concrete architecture repeatedly maligned it by arguing that it was "German" in spirit and origin; see Fabre, "La reconstruction des églises dévastées," 310. This debate particularly crystallized around the Perrets' 1913 Théâtre des ChampsÉlysées; see Legault, "L'appareil de l'architecture moderne," 120-23. Paul Jamot complained about this bias in a 1926 article on the Perrets' proposal for the Basilica of Sainte-Jeanne-d'Arc in Paris, another votive church project meant to mark the Great War: "We sadly note that many prejudices against concrete subsist here. It is a Frenchman who invented it eighty years ago and it is French engineers who applied it first in practice. Yet this remained in the domain of engineers. In terms of architectural applications, we have been outstripped by the Germans. When finally the Perrets and a few others wanted to found a new architecture upon reinforced concrete, those who called themselves guardians of tradition claimed to stifle this renaissance by accusing it of Germanism." Paul Jamot, "Les Frères Perret et la basilique Sainte Jeanne d'Arc," L'Art vivant (1 Sept. 1926), n.p. On the French tendency to brand German society as heartless and mechanistic, see Léon Daudet, Contre l'esprit allemand: De Kant à Krupp (Paris: Bloud et Gay, 1915); Henri Bergson, La signification de la guerre (Paris: Bloud et Gay, 1915).

106. Auguste Perret to Jacques-Émile Blanche, 20 July 1925, dossier 535 AP 330, Fonds Perret, CAA, cited in Legault, "L'appareil de l'architecture moderne," 251. See also Legault, 387, 442, 446; as well as Yvanhoé Rambosson, "L'apport français dans les arts appliqués modernes, l'architecture et la décoration fixe," La Revue de la femme, no. 15 (Mar. 1928), 37, dossier 535 AP 414/ 2, Fonds Perret, CAA.

107. Cyril Simonnet, Le béton, histoire d'un matériau: Économie, technique, architecture (Marseille: Parenthèses, 2005); Frank Newby, ed., Early Reinforced Concrete (Aldershot, England: Ashgate, 2001). On the intertwining of nationalist ideologies and reinforced concrete, see Adrian Forty, Concrete and Culture: A Material History (London: Reaktion, 2012), chap. 4. 